\title{
Determinants of Bank Interest Margins in the Caucasus and Central Asia
}


Determinants of Bank Interest Margins in the Caucasus and Central Asia

Raja Almarzoqi and Sami Ben Naceur 


\title{
IMF Working Paper
}

Middle East and Central Asia Department

\section{Determinants of Bank Interest Margins in the Caucasus and Central Asia ${ }^{1}$ Prepared by Raja Almarzoqi and Sami Ben Naceur}

Authorized for distribution by: Raja Almarzoqi

April 2015

IMF Working Papers describe research in progress by the author(s) and are published to elicit comments and to encourage debate. The views expressed in IMF Working Papers are those of the author(s) and do not necessarily represent the views of the IMF, its Executive Board, or IMF management.

\begin{abstract}
In this paper, we use a bank-level panel dataset to investigate the determinants of bank interest margins in the Caucasus and Central Asia (CCA) over the period 1998-2013. We apply the dealership model of Ho and Saunders (1981) and its extensions to assess the extent to which high spreads of banks in the CCA can be related to bank-specific variables, to competition, and to macroeconomic factors. We find that interest spreads are affected by operating cost, credit risk, liquidity risk, bank size, bank diversification, banking sector competition, and macroeconomic policies; but the impact depends on the country.
\end{abstract}

JEL Classification Numbers: E42, G20

Keywords: Interest margins, Operating costs, Market power, Macroeconomic policies

Authors’ E-Mail Addresses: RAlmarzoqi@imf.org, $\underline{\text { SBenNaceur@imf.org }}$

\footnotetext{
${ }^{1}$ We would like to thank Erikson von Allmen (MCM), Demien Puy (RES) and Sola Sergio (MCD) for their detailed comments. Rafik Selim provided excellent research assistance, Kia Penso excellent editing, and Cecilia Prado and Patricia Poggi editorial assistance.
} 


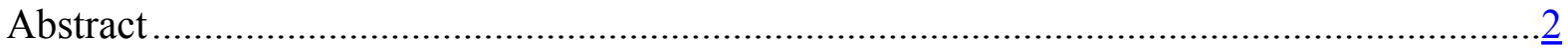

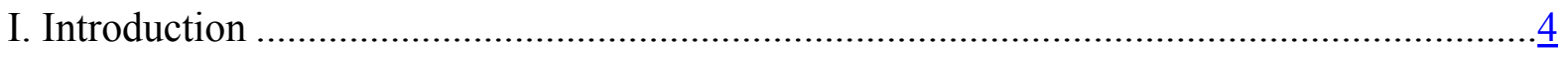

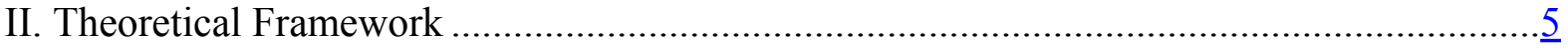

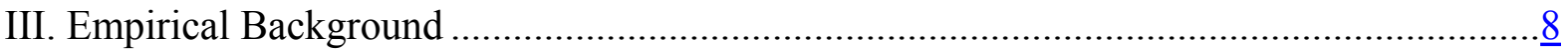

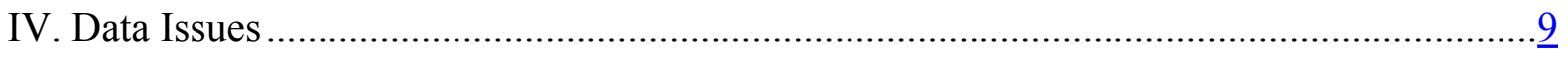

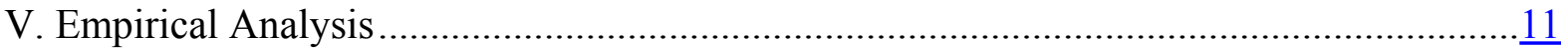

VI. Conclusion and Policy Implications ............................................................. 13

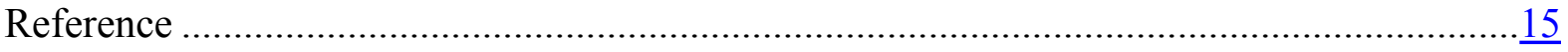

Tables

Table 1: Sample Composition by Country and Year ......................................................19

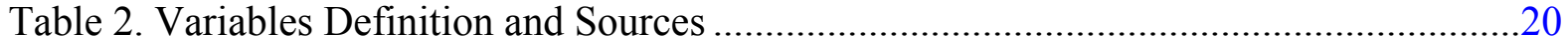

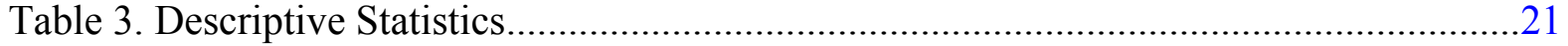

Table 4: Determinants of Bank Interest Margins in the CCA …..........................................22

Table 5: Determinants of Bank Interest Margins in Armenia................................................23

Table 6: Determinants of Bank Interest Margins in Azerbaijan ..........................................24

Table 7: Determinants of Bank Interest Margins in Georgia.............................................25

Table 8: Determinants of Bank Interest Margins in Kazakhstan .......................................26

Table 9: Determinants of Bank Interest Margins in Tajikistan..........................................2

Table 10: Determinants of Bank Interest Margins in Uzbekistan.......................................28

Table 11: Determinants of Bank Interest Margins: Summary of Results .............................29 


\section{INTRODUCTION}

The net interest margin (NIM), measured as the difference between interest income and interest expenses, is widely regarded as an indicator of intermediation efficiency or the cost of intermediation. Efficient intermediation is one of the most important functions of the banking system in supporting economic growth. To avoid high NIMs, banks need to be both efficient and competitive. As in most developing countries, NIMs in the countries of the Caucasus and Central Asia (CCA) have been high since independence. In international comparisons, CCA countries have high banking margins, which may impede financial development: high lending rates discourage investment and low deposit rates reduce saving, hindering growth.

Understanding why interest spreads in CCA countries are so high is, therefore, important for policymakers. The results of this study will highlight what policies are needed to lower intermediation costs. These lower costs will spur growth and boost private investment by deepening the financial system.

This paper investigates the factors behind the high interest spreads in CCA

Figure 1. Financial Deepening and Net Interest Margin (In percent)

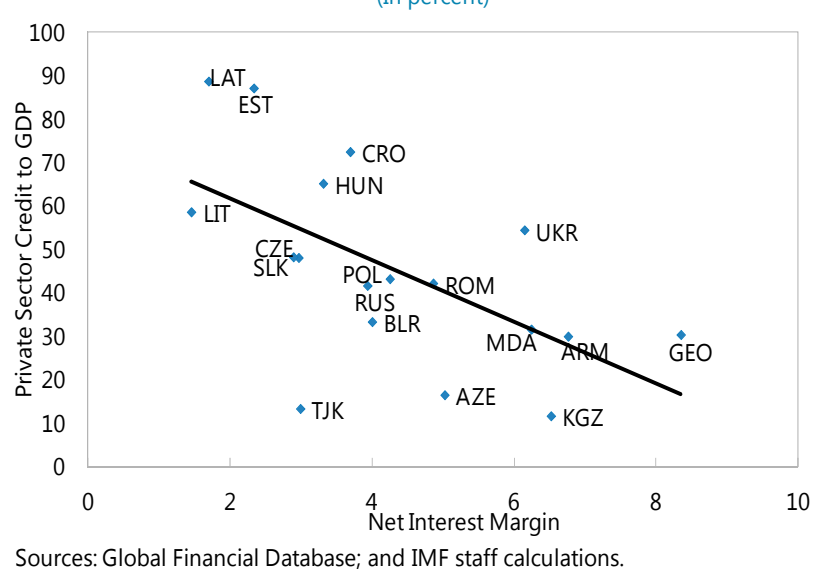

Sources: Global Financial Database; and IMF staff calculations. countries' banking sectors during 19982013. It makes several contributions to the literature on interest spreads and margins. First, it contributes to a small literature on financial development in the CCA. Second, it uses a unique panel dataset comprising balance-sheet and income statements of the CCA's 110 largest banks. Third, it uses, in addition to a pooled OLS estimator, the fixed-effect panel estimator, to account for bank-specific effects, and the Arrelano and Bover (1995) system GMM estimator to solve the endogeneity problem and account for the persistence of the net interest margins.

Our results provide strong support for the importance of bank-specific factors (operating costs, bank size, bank liquidity, and diversification), and the macroeconomic environment in explaining the interest rate variation in CCA countries. High operating costs, lack of competition, and diseconomies of scale for small banks remain key impediments that prevent interest spreads from declining in some CCA countries.

The remainder of the paper is organized as follows. Section B describes the methodology. Section C specifies the data and variables. Section D presents the empirical results. Finally, Section E contains concluding remarks and a number of policy implications. 


\section{THEORETICAL FRAMEWORK}

The seminal paper of Ho and Saunders (1981) has been the reference framework for analyzing the determinants of interest margins. ${ }^{2}$ Their model extends and integrates the hedging and expected utility maximization approaches (Pyle, 1970) and draws heavily on the bid-ask prices for securities (Ho and Stoll, 1980). The bank in the model is viewed as a riskaverse dealer between the demanders and suppliers of funds. The bank will ask for a positive interest spread for providing immediate liquidity service and risking a possible mismatch between the arrival of deposit surplus and loan demand. The net interest spread equals:

$s=R_{L}-R_{D}=(a+b)$

where $R_{L}$ is the rate on loans, $R_{D}$ is the rate on deposits, $a$ is the fee charged by the bank to provide immediacy of liquidity service, and $b$ is the risk premium charged by banks to compensate for refinancing risk.

According to the Ho and Saunders model, the optimal spread is:

$S=(a+b)=\frac{\alpha}{\beta}+\frac{1}{2} R \sigma_{I}^{2} Q$

where the term $\alpha / \beta$ represents the net interest spread required by a risk-neutral bank, given competitive conditions ( $\alpha$ and $\beta$ are respectively the intercept and slope of the symmetric deposit and loan arrival functions). $R$ corresponds to the bank's management coefficient of risk aversion, $\sigma_{I}^{2}$ is the variance of the interest rate on deposits and loans and $Q$ is the bank transaction size. The model shows that the optimal interest spread is a function of four factors: (i) the degree of bank risk-aversion; (ii) the degree of competition in the market where the bank operates; (iii) the interest rate risk; and (iv) the average transaction size.

Over the years, some simplifying assumptions of the Ho and Saunders model were relaxed. Allen (1988) considered loan heterogeneity in the model (banks offer different types of deposits and loans) and showed that pure interest margins may be reduced as a result of diversification of bank services and products. McShane and Sharpe (1985) replaced the volatility of the deposit or lending rates, as in Ho and Saunders, with the volatility of the money market interest rate. Angbazo (1997) extended the Ho and Saunders model by incorporating credit risk and its interaction with interest rate risk. Carbo and Rodriguez (2007) developed the model of Ho and Saunders by including both traditional and nontraditional activities in order to study the effect of specialization on bank spreads, using a multi-output model for European banking. Maudos and Fernandez de Guevara (2004) extended the Ho and Saunders model to take banks' operating costs explicitly into account, and used a direct measure of the degree of competition (the Lerner index) in addition to the

\footnotetext{
${ }^{2}$ Zarruk (1989), Zarruck and Madura (1992), and Wong (1997) derive an alternative model to explain the bank's optimal spread in which banks are assumed to set the deposit and loan rate simultaneously.
} 
degree of concentration of the market (Herfindahl index). Under these extensions, it is shown that the optimal spread is :

$s=\frac{1}{2}\left(\frac{\alpha_{D}}{\beta_{D}}+\frac{\alpha_{L}}{\beta_{L}}\right)+\frac{1}{2}\left(\frac{C(D)+C(L)}{2 Q}\right)-\frac{1}{4} R \times\left[\left(L+2 L_{0}\right) \sigma_{L}^{2}+(L+D) \sigma_{M}^{2}+2\left(M_{0}-L\right] \sigma_{L M}\right.$

The term $\alpha / \beta$ is a proxy of market power, $L$ are loans, $D$ are deposits, $Q$ is the average size of the bank's operations, $R$ is a measure of absolute risk aversion, $\sigma_{L}^{2}$ is the credit risk, $\sigma_{M}^{2}$ is the volatility in the money market interest rate (represent reinvestment and refinancing risk), $\sigma_{L M}$ is the interaction between credit risk and market risk, and $C$ is the operating costs.

The empirical literature suggests five main determinants of banks' interest margins: bankspecific factors, market structure, regulation, institutional environment, and the macro economy. Many empirical studies have expanded and examined the dealership model using cross-country samples or focusing on a single developed or developing country.

Empirical studies on interest margin determinants often use bank operating cost, managerial efficiency, credit risk, liquidity risk, interest rate risk, implicit interest payment, bank size, capital adequacy ratio, and non-interest income share as bank-specific variables. There is consensus among studies that the net interest margin is positively related to operating costs, and there is agreement that banks pass these costs on to customers (Maudos and Fernandez de Guevara 2004; Williams 2007; and Hess 2007, among others).

Most of the papers on the determinants of interest margins show that credit risk-proxied by nonperforming loans (NPLs) to total assets and loan loss provision to total assets-exert a positive effect on interest margins (Maudos and Fernandez de Guevara 2004; Angzabo 1997; and Maudos and Solis 2009, among others), which means that banks charge additional risk premiums to compensate for credit risk. Williams (1997) and Hess (2007) found a negative association between credit risk and net interest margins, attributing this result to weak banks that decrease margins to cover expected loses (Chortareas and others 2010).

With regard to risk aversion (proxied by the capital adequacy ratio), the findings are also mixed: Saunders and Schumacher (2000) and Brook and Rojas (2000) found that the capital adequacy ratio has a positive and significant impact on banks' spreads, confirming the assumption that banks ask for higher margins to compensate for better tax treatment of debt over equity. In contrast, margins are decreasing in banks' capital adequacy in Armenia (Dabla-Norris and Floerkemeier 2007) and the Czech Republic (Horvath 2009), reflecting that well-capitalized banks charge lower spreads for their lower risk of bankruptcy and greater stability.

The literature presents contrasting results on the relationship between bank margins and size (proxied by the natural logarithm of loans or total assets). Ho and Saunders (1981), and Maudos and Solos (2009) find a positive relationship because the larger the transaction, the larger the potential loss will be. Fungacova and Poghosyan (2009), Maudos and Fernando de 
Guevara (2004), and Angbazo (1997), among others, report a negative association between bank size and interest margins, pointing to the cost reduction attributed to economies of scale.

More recent studies find that banks with well-developed non-interest income sources have lower net interest margins; this suggests that banks may tend to offer loans with small or even negative margins to attract clients and compensate with higher fees (LePetit and others 2008; Maudos and Solis 2009; and Carbo and Rodriguez 2007, among others). Others, such as Elsas (2005) and De Gryse (2007), find that higher bank competition reinforces banks' focus on traditional loan activity, increasing net interest margins.

There is no generally accepted model for including macroeconomic variables to control for the effect of macroeconomic conditions on the evolution of bank interest margins, except the Ho and Saunders dealership model and its extension, which includes the volatility of interest rates.

Empirical research in the determinants of net interest margins showed a positive relationship between interest rate risk (interest rate volatility) and bank interest margins (Angbazo 1997; Hwatrey and Liang 2008; and Saunders and Schumacher 2000, among others). Laeven and Majnoni (2005), Demirguc-Kunt and others (2004), and Claeys and Van Vennet (2008), among others, found a positive effect of inflation on interest margins through higher loan interest rates (this positive relationship may capture information asymmetries or macroeconomic volatility). Other studies such as Abreu and Mendes (2003) and Maria and Agoraki (2010) found a negative relationship between inflation and interest rate margins, indicating that bank costs increase more than bank revenues do, most probably because of regulatory constraints on adjusting lending rates.

The empirical evidence as to the impact of market structure on bank interest margins provides conflicting results. Some studies found that net interest margins tend to increase with bank concentration and market power (Angbazo 1999; Williams 2007; Saunders and Schumacher 2000; and Maudos and Solis 2009, among others). Demirguc-Kunt and others (2004) found that the positive association between concentration and bank margins disappears when institution quality variables are included. Beck and Hess (2009) reject the positive association between concentration and bank margins, suggesting that contestability and other nonprice factors are better measures of bank competition. Claessens and Laeven (2004) attribute the absence of links between market structure and banks' spreads to the fact that concentration variables are not good proxies for the degree of competition in the banking sector.

One variable overlooked by the dealership model that could explain the net interest margin is the ownership of banks. Martinez and Mody (2004) and Drakos (2003) found that foreign banks realize lower margins than domestic banks in transition countries. The opposite conclusion is reached by Schwaiger and Liebig (2008) on a sample of CEE countries, though 
Dabla-Norris and Floerkemeier (2007) find no effect of foreign ownership on bank interest margin in Armenia. Few papers examine the relationship between regulation costs and net interest margins. Brock and Suarez (2000), Saunders and Schumacher (2000), and Gelos (2006) find that higher reserve requirements at the central bank lead to higher interest margins.

\section{EMPIRICAL BACKGROUND}

Our empirical analysis is based on the framework of the Ho and Saunders (1981) model and its subsequent extensions. The most recent framework for the bank dealership model is given by Maudos and Fernandez de Guevara (2004), in which the theoretical motivated drivers of the net interest margins comprise operating costs, managerial risk aversion, credit risk, liquidity risk, interest rate risk, bank size, and market structure. Our model supplements Maudos and Fernandez de Guevara by adding macroeconomic and regulation variables, and is specified as follows:

$N I M_{i, t}=\alpha+\beta \mathrm{BSV}_{i, t}+\gamma \mathrm{MS}_{t}+\delta \mathrm{ME}_{t}+\theta \mathrm{INS}+\mu_{i}+v_{i, t}$

where $i$ and $t$ stand for bank $i$ at time $t$. NIM is the bank's interest spread, BSV is a vector of theoretically motivated determinants of bank spread, while MS, ME and INS are vectors of market structure, macroeconomic and institutional variables respectively, $\mu_{i}$ is a bank-specific error term to capture individual bank heterogeneity, and $v_{i, t}$ is an i.i.d random error.

Three different empirical approaches have been used to estimate the above model: (i) the first method uses a two-step procedure, in which the first step, cross-sectional regressions of net interest margins of individual banks, is performed in each country for each period; in the second step, the time series of pure interest margins is regressed on a set of market structure and interest volatility. This approach is only feasible with a long time series and a large cross-section of observations (see Brock and Suarez 2000; Agbanzo 1997; Saunders and Schumacher 2000); (ii) the second method uses a single-step procedure that includes all the theoretical and other determinants of the net interest margins. This approach has used pooled OLS, pooled WLS, and GLS estimators (Kasman 2010; Claeys and Vander Vennet 2008; Maudos and Fernandez de Guevara 2004); and (iii) the third method uses a single-step procedure like the second method, but it accounts for the persistence of net interest margins over time and controls for endogeneity. In terms of estimation technique, this approach uses a GMM estimator (Maudos and Solis 2008; Horvath 2009, Garcia-Herrero, Gravity, and Santa Barbara 2009; and Dietrich and Wanzenried 2011). As our data set covers only 10 years, we will use only the second and third approach.

In addition to using pooled OLS with robust errors to estimate the coefficient in our models, equation 4 is estimated with panel data estimators to capture the impact of specific variables of each bank. A Fisher test is used to determine whether our data require panel data estimation or pooled OLS. Panel data models are estimated using either the fixed-effects or 
random-effects estimators. A Hausman test is used to determine whether a fixed-effect (leastsquare Dummy Variables) or random-effect estimator is appropriate. Because the dependent variable is likely to be persistent and the unobserved time-invariant bank-specific effect is correlated with the explanatory and dependent variables, a first differencing is needed to eliminate the bank-specific effects. To address this inertia and possible endogeneity problems, we use the system GMM estimators of Arellano and Bover (1995) and Blundell and Bond (1998), which combine the standard set of equations in first-differences and an additional set of equations in levels. To address the potential endogeneity, ${ }^{3}$ lagged levels and lagged differences of the explanatory variables are used as instruments. To test the validity of the model, a Hansen over-identifying test and second-order serial correlation of the firstdifference residuals will be used (The system GMM will be applied to the entire CCA sample and not to individual countries because such estimator requires large $\mathrm{N}$ and small $\mathrm{T}$ to provide consistent estimates). We therefore estimate the following dynamic model:

$$
N I M_{i, t}=\alpha+\beta N I M_{i, t-1}+\gamma \mathrm{BSV}_{i, t}+\delta \mathrm{MS}_{t}+\eta \mathrm{ME}_{t}+\theta \mathrm{INS}+\mu_{i}+v_{i, t}
$$

\section{DATA Issues}

The sample is formed of an unbalanced panel of 110 commercial and savings banks for the period between 1998 and 2013, described in Table 1. Bank-level data in the sample were taken from the Bankscope database, the data on macroeconomics were obtained from the IMF's International Financial Statistics, and data on market structure from the World Bank's Global Financial Development Database (GFDD). Table 2 describes the variable definitions, as well as data sources and expected relationship with bank margins.

We use as a dependent variable the bank's net interest margin, defined as interest income minus interest expenses divided by total assets, which measures also the cost of financial intermediation.

Based on the theory of the determinants of bank interest margins (see Maudos and Fernandez de Guevara [2004] for the most recent framework for the bank dealership model), the bankspecific variables considered in our estimation are as follows:

- Operation efficiency proxies for the cost of servicing and monitoring transactions, among others, and is measured by the ratio of operating expenses to total assets. Less efficient banks, experiencing larger operating costs, tend to require higher margins. A positive coefficient on this variable is expected.

- $\quad$ Risk aversion is proxied by the ratio of equity to total assets. A higher ratio indicates higher risk aversion on the part of bank managers. The expected sign on this variable

\footnotetext{
${ }^{3}$ Following Maudos and Solis (2009) and Garza-Garcia (2010), we will consider that the Lerner index is endogeneous, because the degree of market power depends on bank margins.
} 
is ambiguous: on the one hand, highly capitalized banks are more solvent, which will reduce their funding costs and, therefore, strengthen their margins; on the other hand, higher risk aversion may encourage banks to invest their resources in less risky assets, producing lower margins (Poghosyan 2012).

- Credit risk is defined by the ratio of loan loss provisions to gross loans. A higher ratio is associated with lower credit quality and high credit risk. Banks are expected to require higher interest margins to compensate for funding riskier projects, and to maintain adequate loan reserves (Poghosyan 2012). An alternative interpretation is that a bank may mitigate high credit risk by investing in low-return government securities (Valverde and Fernandez 2007).

- Size of operation is proxied by the logarithm of loans. The theoretical literature does not provide an unequivocal answer as to the relationship of the volume of loans and the interest margin. On the one hand, larger transactions spread operating costs over a larger base, which enables large banks to achieve lower interest spreads (economies of scale). On the other hand, the larger the operation, the larger the potential loss will be, resulting in a positive relationship between the volume of loans and net interest spreads.

- Bank diversification is measured by the ratio of non-interest income to total assets. A diversified bank is expected to offer its interest-dealing activities with lower spreads, to attract new customers, and to compensate for these opportunity costs by higher fees and commissions (see Petit and others [2007] for cross-subsidization strategy); hence, a negative sign is expected.

- $\quad$ Reserve requirement is used to capture the regulatory costs, and is proxied by the ratio of cash plus balances with central banks to total assets. The opportunity cost corresponds to the additional interest rate that banks can obtain by investing reserves in the financial market. A positive correlation with the interest margin is expected because the larger the amount of reserves at the central bank, the greater the opportunity cost, and the higher the spreads needed to compensate for the missing interest.

Competition is measured by the Lerner index instead of the concentration ratio, because the latter cannot provide a satisfactory measure of the degree of market competition in the banking sector (see Beck and Hess 2009). The Lerner index is the difference between the price and the total marginal costs (operating + financial) as a proportion of the price. ${ }^{4} \mathrm{~A}$ lower Lerner index indicates a strong degree of competition in the banking sector, which

\footnotetext{
${ }^{4}$ The price is proxied by total revenues, and the marginal cost is estimated from a translog total cost function (see Maudos and Solis, 2009 for more details on the methodology).
} 
results in lower margins; ${ }^{5}$ therefore, a positive relationship between the Lerner index and the interest margins is suggested: banks with greater market power can fix higher spreads than they could in a more competitive market.

Among macroeconomic factors, inflation and the policy rate are included. The CPI variable is calculated as the year-end change in CPI, and is expected to have a positive relationship with net interest margins (see Boyd and others 2001; and Gelos 2006) because higher inflation introduces economic uncertainty that needs to be compensated by higher spreads (Poghosyan 2012). The policy rate is the refinancing rate at the central bank, and it controls for monetary policy.

We add in our CCA sample, institutional variables such as the credit depth of information, the strength of legal rights and the institutional quality because improved financial infrastructures could reduce risk and improve the cost of intermediation. ${ }^{6}$

\section{EMPIRICAL ANAlysis}

Table 3 shows descriptive statistics of the net interest margin and its determinants for the total sample as well as for subsamples of countries. The regressions in Table 4 provide evidence for the determinants of bank interest margins at the regional level using the dynamic GMM estimator. The failure to reject the null hypothesis of both the Hansen and the second serial correlation tests lends support to using the dynamic system GMM. Besides, the significance of the lagged dependent variable demonstrates the importance of using a dynamic specification for the regional sample.

The first column in Table 4 presents a regression with only bank-level explanatory variables. The results show that in the CCA, operating costs, size of operations, and opportunity cost of reserves are positively and significantly associated with the net interest margin, as is consistent with theory and previous empirical evidence. This suggests that larger banks incurring greater operational cost, and with large amount of reserves at the central bank, operate with higher margins. The coefficient on non-interest activity is negative and significant, which shows that banks, highly specialized in lending, exhibit higher interest margins in the CCA. Columns 2-7 show that credit risk, market structure, and the macroeconomic environment do not enter significantly into the net interest margin regressions in the CCA region.

Tables 5-10 provide evidence for the determinants of the net interest margins for each country using different estimators (OLS, GLS, Fixed-Effect, and RREG). Table 11

\footnotetext{
${ }^{5}$ The value of the Lerner index ranges from 0 (perfect competition) to 1 (monopoly).

${ }^{6}$ The variables are not included in the country regressions because they change slowly across time.
} 
summarizes the economic impact of the explanatory variables on the net interest margins, to compare the importance of the coefficients.

We first consider the bank-specific determinants of net interest spreads in the first three columns of Tables 5-10. The coefficients of the operating expenses variable are significant and positive in all estimations, indicating that a bank with high operating costs will pass them on to consumers in the form of wide margins, especially if the banking environment is not competitive. The result suggests that more efficient banks pass lower administrative costs on to their customers through higher deposit or lower lending rates (Claeys and Vander Vennet 2008; and Horvath 2009) This result is consistent with that obtained by Maudos and Fernandez de Guevara (2004) for European banks, Williams (2007) for Australian banks, Horvath (2009) for Czech Banks, Mados and Solis (2009) for Mexico, and Gelos (2006) for Latin American banks.

The results of the size of operations on explaining the NIM are mixed. The coefficient of the Size of Operation variable in Armenia is significant and positive, while in Azerbaijan and Uzbekistan the coefficients are negative and significant. Theories emphasize economy of scale in intermediation costs; but they contradict the supposition that large banks in a small country may impose their market power by raising spreads (Horvath 2009). The negative result is in line with Horvath (2009) for Czech Banks, Gelos (2006) for Latin American banks, Maudos and Fernandez de Guevara (2004) for European banks, and Fungacova and Poghosyan (2011) for Russian banks; whereas results for Georgia, Kazakhstan, and Tajikistan are similar to findings in Claeys and Vander Vennet (2008) and Schwaiger and Liebig (2008), who find no relationship in new EU member banks and Central and Eastern Europe, respectively.

Although a positive correlation was expected between the net interest margin and credit risk, this correlation was negative and significant for some countries. The credit risk coefficients for Azerbaijan and Kazakhstan are negative and significant, while insignificant for other countries in the sample, except Uzbekistan, where, in some models, the coefficient turns out to be positive. These results confirm the findings of Fungacova and Poghosyan (2011) for Russian banks, Gunter and others (2013) for Austrian banks, and William (2007) for Australian banks. These findings could be attributed to mispricing of risk, because higher levels of provisions for NPLs would not be fully compensated for by net interest spreads (DeYoung and Nolle 1996; and Williams 2007). Moreover, inadequate accounting standards and inappropriate classification of loan loss provisions might also make the concept of credit risk irrelevant.

The reserve requirement is another monetary or regulatory policy tool that could affect the cost of intermediation; its proxy, the opportunity cost of bank reserves variable, is positively and significantly associated with spreads in most of the regressions. This result is consistent with Brock and Suarez (2000) and Saunders and Schumacher (2000), who argue that higher 
reserve requirements are translated into higher interest spreads to compensate for the missing incomes resulting from zero or low return on reserves.

The non-interest-income variable has a significant negative coefficient for all the regressions, suggesting cross-subsidization of fee- and commission-generating activities with traditional lending activities (Carbo and Rodriguez 2007; and Le Petit and others 2008). More diversified banks could charge lower spreads for loans to gain higher income from noninterest activities, because they consider the two sources of income as substitutes for each other (Kalluci 2010).

Tables 5-10 also report results for net interest margin, including market structure and macroeconomic variables, in columns 4-9. With respect to the market structure variables, the Lerner index, a proxy of market power, has the expected positive and significant sign in most of the countries (except in Uzbekistan, where the coefficient is insignificant, and in Tajikistan, where the information needed to compute the Lerner index is not available) in line with Liebig and Schawaiger (2006), Maudos and Solis (2009), and Entrop and others (2012). These results reveal that banks with market power can charge higher lending rates and offer lower deposit rates. The results also show that macroeconomic conditions affect net interest margins in some countries: higher inflation is associated with higher margins in Armenia, Azerbaijan, and Georgia, which suggests that bank net interest margins increase with inflation. Inflation negatively and significantly affects the net interest margin in Kazakhstan and Tajikistan, while it is insignificant in Uzbekistan. Also of interest, the policy rate is positive and significant in Azerbaijan and Georgia, which suggests that stable prices, combined with low policy rates, are essential for reducing interest margins.

Table 11 shows the economic significance instead of the statistical coefficients for each variable in all specifications using standardized variables. ${ }^{7}$ The advantage of this approach over statistical significance is that we use comparable coefficients. The results indicate the comparatively large impact of operating costs, the size of operation, and market power on net interest margins in the CCA region.

\section{Conclusions and Policy Recommendations}

The results show that operational efficiency is by far the most important driver of interest spreads in CCA countries. Higher operating costs are reflected in higher interest spreads. Size turns out to be another important determinant of bank spreads, and we interpret this finding as evidence of the existence of room for consolidating the banking sector in CCA countries. We find also that higher market power increases interest spreads in some countries. Our results show that banks that rely heavily on fee-based activities have lower

\footnotetext{
${ }^{7}$ The economic significance coefficients are obtained by using standardized variables $z=(x-\mu) / \sigma$ where $\mu$ is the mean of the population; and $\sigma$ is the standard deviation of the population.
} 
lending rates that underprice credit risk (cross-subsidization may distort risk exposures) and could raise issues for bank regulation and competition with nonbank lenders (See Petit and others, 2008).

Another interesting result is that capital adequacy is not a statistically significant explanatory variable for bank interest margins in most of the countries, except Armenia, where higher capitalization is compensated by higher margins. This result may reflect the fact that capital in some countries is fictitious, calling into question the value of assets and collateral and the provisioning of NPLs. In the same vein, a negative correlation between credit risk and interest margins reflect inadequate interest spreads (mispricing of risks) to compensate for provisions for NPLs.

Aside from the bank-specific and market structure variables, the macroeconomic environment - proxied by the inflation rate and the policy rate - has a significant impact on interest margins, though the extent of the impact differs from country to country. Generally, a stable macroeconomic environment, with low inflation, low interest rate, and low reserve requirement, will support lower net interest margins.

The analysis suggests that it is important to reduce operating costs, to increase competition, to consolidate the small bank segments and to maintain a stable macroeconomic environment to lower bank interest margins. Specifically, reducing operating costs could be achieved by enhancing banking sector competition and consolidation; adopting the best banking technologies such as mobile banking, internet banking, and ATMs, to reduce the need for a large branch network; improving staff training and management practices; strengthening bank corporate governance; introducing organizational changes (such as outsourcing); opening the market for foreign banks; and building a consumer credit database.

Enhancing competition in the banking sector could be achieved by: reducing restrictions on entry into and exit from the market; privatizing public banks; treating all banks equally and avoiding special treatment that leads to market power; promoting nonbank financial institutions and capital markets; and reducing loan concentration though stricter supervision of large exposures. Because small banks in some of the CCA countries are operating with significant unrealized economies of scale, the authorities could allow for market-led consolidation of smaller banks, which will contribute to greater cost efficiency and lower interest rate spreads. The authorities in the region should allow small nonperforming banks to exit the market; and encourage the healthier banks to merge or acquire weaker banks by ensuring that bureaucratic and procedural formalities are minimal.

Lowering reserve requirements is likely to reduce the cost of intermediation. Because credit risks are underestimated and capital non-significant in explaining interest rate spreads, there is a need to strengthen the identification of NPLs and loan loss provision implementation rules, to improve risk management techniques, and to address deficiencies in supervisory practices. 


\section{References}

Abreu, M., and V. Mendes, 2003. "Do macro-financial variables matter for European bank interest margins and profitability?" Paper presented at EcoMod Network Conference, Istanbul.

Allen, L., 1988. "The determinants of bank interest margins: A note." Journal of Financial and Quantitative Analysis Vol. 23 (2): pp. 231-235.

Angbazo, L., 1997. "Commercial bank Net Interest Margins, default risk, interest rate risk and off balance sheet banking." Journal of Banking and Finance 21, pp. 55-87.

Arellano, M., O. Bover, 1995. "Another look at the instrumental-variable estimation of errorcomponents models.” Journal of Econometrics Vol. 68 (1), pp. 29-51.

Beck, T., and H. Hess, 2009, "Why Are Interest Spreads So High in Uganda?" Journal of Development Economics, Vol. 88, pp. 192-204.

Bernanke, B. S. and M. Gertler, 1990. "Financial Fragility and Economic Performance." The Quarterly Journal of Economics, Vol. 105 (1), pp. 87-114.

Blundell, R.W., and S. R. Bond, 1998. "Initial conditions and moment restrictions in dynamic panel data models.” Journal of Econometrics Vol. 87, pp. 115-143.

Boyd, J., R., Levine, and B. Smith, 2001. "Inflation and financial market performance." Journal of Monetary Economics Vol. 47 (2), 221-248.

Brock, P.L., and L. Rojas, 2000. Understanding the behavior of bank spreads in Latin America. Journal of Development Economics Vol. 63, pp. 113-134.

Carbó, S., F. Rodriguez, 2007. The determinants of banks' margins in European banking. Journal of Banking and Finance Vol. 31, pp. 2043-2063.

Chortareas, Georgios E., Claudia Girardone, and Jesus Gustavo Garza-Garcia, 2010. "Banking Sector Performance in Some Latin American Countries: Market Power versus Efficiency," Working Papers 2010-20, Banco de México (Mexico City).

Claessens, Stijn, and Luc Laeven, 2004. "What Drives Bank Competition? Some International Evidence.” Journal of Money, Credit and Banking, Vol. 36, pp. 563-584.

Claeys, S., R. Vander Vennet, 2008. "Determinants of bank interest margins in Central and Eastern Europe: a comparison with the West.” Economic Systems Vol. 32, pp. 197-216.

Dabla-Norris, E. and Floerkemeier, H. (2007). Bank Efficiency and Market Structure: What Determines Banking Spreads in Armenia? Washington, International Monetary Fund (IMF), Working Paper No. 07/134. 
Degryse, Hans, and Steven Ongena, 2007. "The impact of competition on bank orientation,"Journal of Financial Intermediation, Vol. 16(3), pp. 399-424, July.

Demirguc-Kunt, A., L. Laeven, and R. Levine, 2004, "Regulations, Market Structure, Institutions, and the Cost of Financial Intermediation," Journal of Money, Credit, and Banking, Vol. 36(3), pp. 593-622.

DeYoung, Robert, and Daniel E. Nolle, 1996, "Foreign-owned banks in the United States: earning market share or buying it," Journal of Money, Credit and Banking Vol. 28, pp. 622636.

Dietrich, A., and G. Wanzenried, 2011, "Determinants of bank profitability before and during the crisis: evidence from Switzerland," Journal of International Financial Markets, Institutions and Money, Vol. 21, pp. 307-327.

Drakos, K., 2002. "The Dealership model for interest margins: The case of the Greek banking industry.” Journal of Emerging Finance Vol. 1, pp. 75-98.

Drakos, K., 2003. "Assessing the Success of Reform in Transition Banking: An Interest Margins Analysis.” Journal of Policy Modeling, Vol. 25(3), pp. 309-317.

Elsas, R., 2005, “Empirical Determinants of Relationship Lending,” Journal of Financial Intermediation, Vol. 14, pp. 32-57.

Entrop, O., C. Memmel, B. Ruprecht, and M. Wilkens, 2012. "Determinants of bank interest margins: Impact of maturity transformation." Working Paper. Deutsche Bundesbank Discussion Paper Series 2: Banking and Financial Studies No 17/2012 (Frankfurt am Main).

Fungáčová, Zuzana \& Poghosyan, Tigran, 2011. "Determinants of bank interest margins in Russia: Does bank ownership matter?" Economic Systems Vol. 35(4), pp. 481-495.

Garcia-Herrero, A., S. Gavila, and D. Santabarbara, 2006. “China's banking reform: an assessment of its evolution and possible impact”, CESifo Economic Studies, Vol. 52, pp. 304-363.

Gelos, R., 2006. Banking Spreads in Latin America. IMF Working Paper WP/06/44, (Washington: International Money Fund).

Ghosh, S., 2008, "Regulatory Pressure, Market Discipline and Bank Spreads in India: An Empirical Exploration," Global Economic Review, Vol. 37(2): pp. 227-47.

Guiso, L., S. Paola, and L. Zingales, 2006. “The Cost of Banking Regulation.” NBER Working Paper 12501 (Cambridge, MA: National Bureau for Economic Research). 
Gunter, U., G. Krenn, and M. Sigmund, 2013. "Macroeconomic, market and bank-specific determinants of the net interest margin in Austria," Financial Stability Report 25. OeNB, pp. 87-101 (Vienna: National Bank of Austria).

Hanweck, G., and L. Ryu, 2005. The Sensitivity of Bank Net Interest Margins and Profitability to Credit, Interest-Rate, and Term-Structure Shocks Across Bank Product Specializations, Working Paper 2005-02, Federal Deposit Insurance Corporation (Washington).

Hawtrey, K., And H. Liang, 2008. "Bank interest margins in OECD countries," North American Journal of Economics and Finance, Vol. 19, 249-260.

Hesse, Heiko, 2007. "Financial intermediation in the pre-consolidated banking sector in Nigeria,"Policy Research Working Paper Series 4267 (Washington: World Bank).

Ho, T.S., and A. Saunders, 1981. "The determinants of bank interest margins: theory and empirical evidence.” Journal of Financial Quantitative Analysis Vol. 16, pp. 581-600.

Ho, Thomas, and Hans R. Stoll, 1980. " On Dealer Markets under Competition," Journal of Finance, American Finance Association, Vol. 35(2): pp. 259-67, May.

Horvath, R., 2009. "Interest Margins Determinants of Czech Banks." Institute of Economic Studies, Faculty of Social Sciences, Charles University, WP 11/09 (Prague).

Kalluci, I. (2010), "Determinants of Net Interest Margin in the Albanian Banking System", Working Paper Series, April, Bank of Albania.

Kasman, A., 2010. "Consolidation and Commercial bank net interest margins: evidence from the old and new European union members and candidate countries." Economic Modeling Vol. 27, pp. 648-655.

Laeven, L., and G. Majnoni, 2005. "Does judicial efficiency lower the cost of credit?" Journal of Banking \& Finance, Vol. 29(7): pp. 1791-1812.

Lepetit, L., E. Nys, P. Rous, A. Tarazi, 2008. « The expansion of services in European banking: implications for loan pricing and interest margins." Journal of Banking and Finance Vol. 32, pp. 2325-2335.

Liebeg, David, and Markus S. Schwaiger.2006. "Determinants of the Interest Rate Margins of Austrian Banks", Oesterreichische National Bank Financial Stability Report, 12(2006), 104-116 (Vienna: National Bank of Austria).

Maria-Elena K. Agoraki ,2010. The Determinants of Net Interest Margin during Transition, Department of Accounting and Finance, Athens University of Economics and Business (Athens). 
Martinez, P., and A.Mody, 2004. "How Foreign Participation and Market Concentration Impact Bank Spreads: Evidence from Latin America," Journal of Money, Credit and Banking, Vol. 36 (3): pp. 511-537.

Maudos, J., and J. Fernández de Guevara, 2004. "Factors explaining the interest margin in the banking sectors of the European Union." Journal of Banking and Finance Vol. 28, pp. 2259-2281.

Maudos, J., and L. Solís, 2009. "The determinants of net interest income in the Mexican banking system: an integrated model." Journal of Banking and Finance Vol. 33, pp. 19201931.

McShane, R.W., and I. G. Sharpe, 1985. "A time series/cross section analysis of the determinants of Australian Trading bank loan/deposit interest margins: 1962-1981." Journal of Banking and Finance Vol. 9, pp. 115-136.

Poghosyan, T., 2010, "Re-Examining the Impact of Foreign Bank Participation on Interest Margins in Emerging Markets," Emerging Markets Review, Vol. 11(4): pp. 390-403.

Poghosyan, T., 2012, "Financial Intermediation Costs in Low-Income Countries: The role of regulatory, institutional, and macroeconomic factors,'IMF Working Paper No. 12/140 (Washington: International Monetary Fund).

Pyle, D.H., and S.J. Turnovsky, "Safety-First and Expected Utility Maximization in MeanStandard Deviation Portfolio Analysis," Review of Economics and Statistics, Vol. 52, pp. 7581.

Saunders, A., and L. Schumacher, 2000. "The determinants of bank interest rate margins: an international study." Journal of International Money and Finance Vol.19, pp. 813-832.

Schwaiger, M.S. and D. Liebeg, 2008, "Determinants of bank interest margins in Central and Eastern Europe," Financial Stability Report 14, 68-84, Österreichische Nationalbank (Vienna).

Williams, B., 2007. "Factors determining net interest margins in Australia: domestic and foreign banks." Financial Markets, Institutions and Instruments Vol. 16, pp. 145-165.

Wong, K.P., 1997. "On the determinants of bank interest margins under credit and interest rate risk," Journal of Banking and Finance Vol. 21, pp. 251-271.

Zarruck, E.R., 1989. "Bank margins with uncertain deposit level and risk aversion.” Journal of Banking and Finance Vol. 13, pp. 797-810.

Zarruk, E., and J. Madura. 1992. “Optimal Bank Interest Margin under Capital Regulation and Deposit Insurance.” Journal of Financial and Quantitative Analysis Vol. 27( 1): pp. 14349. 


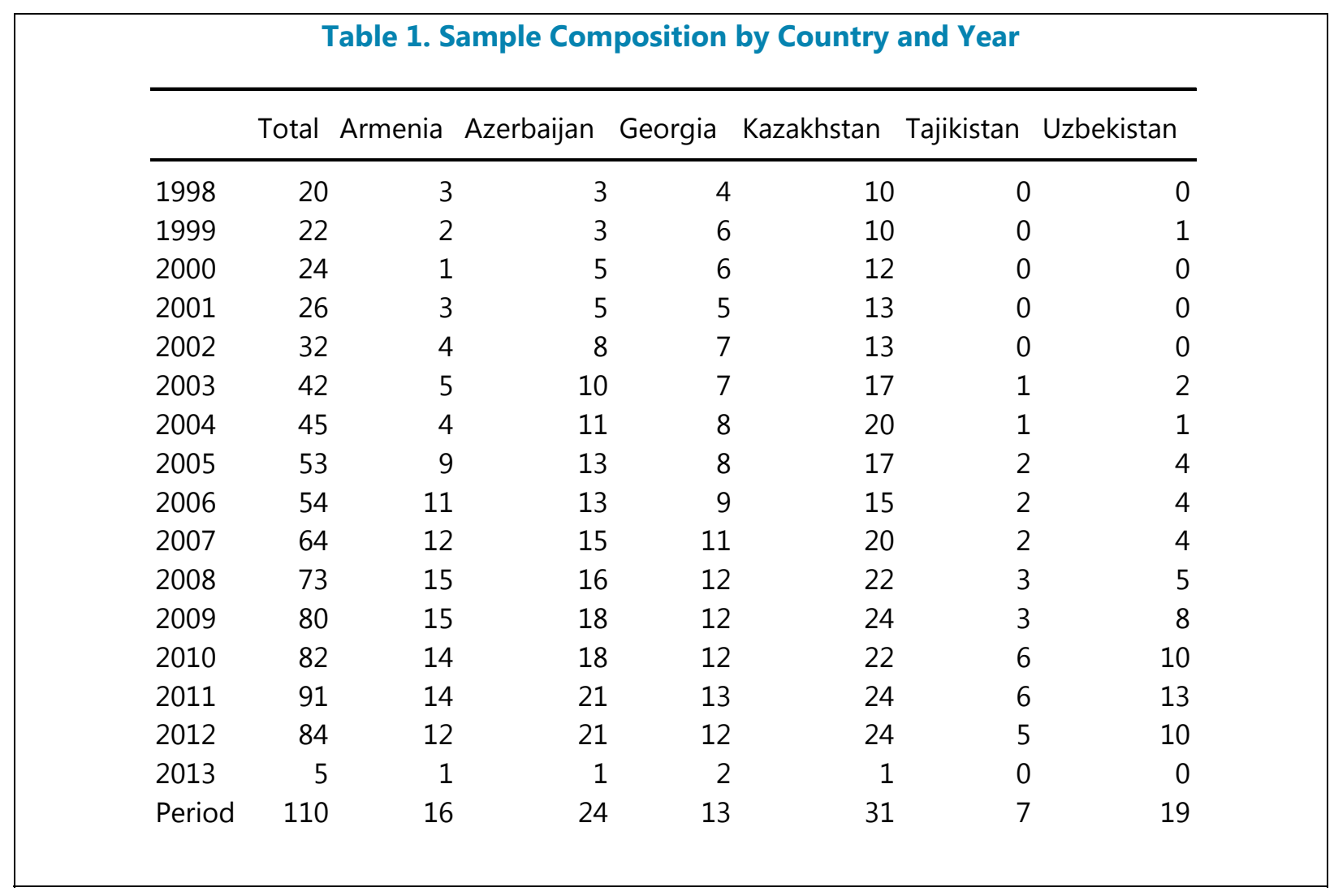




\begin{tabular}{|c|c|c|c|}
\hline \multicolumn{4}{|c|}{ Table 2: Variables Definition and Sources } \\
\hline Variable & Definition & Source & Expected Sign \\
\hline Net Interest Margin (NIM) & Net Interest Margin & Bankscope & Dependent \\
\hline Operating Cost $(\mathrm{OC})$ & Overheads to Total Assets & Bankscope & + \\
\hline Risk Aversion (RA) & Equity to Total Assets & Bankscope & $?$ \\
\hline Credit Risk (CR) & Loan Loss Reserves to Gross Loans & Bankscope & + \\
\hline Size of Operation (SO) & Log of Total Assets & Bankscope & + \\
\hline Non-interest Activity (NIA) & Non-Interest Income to Gross Revenues & Bankscope & - \\
\hline Opportunity Cost of Reserves & Cash to Total Assets & Bankscope & $?$ \\
\hline Lerner Index (LERNER) & $\begin{array}{l}\text { The difference between total revenue and total } \\
\text { cost divided by the total revenue as a proxy for } \\
\text { market power }\end{array}$ & $\begin{array}{l}\text { Global Financial } \\
\text { Development Database }\end{array}$ & + \\
\hline Inflation (INF) & $\begin{array}{l}\text { Annual rate of change in the average consumer } \\
\text { price index }\end{array}$ & $\begin{array}{l}\text { International Financial } \\
\text { Statistics }\end{array}$ & + \\
\hline Policy Rate (PR) & Monetary Policy-Related Interest Rate & $\begin{array}{l}\text { International Financial } \\
\text { Statistics }\end{array}$ & + \\
\hline $\begin{array}{l}\text { Credit Depth of Information } \\
\text { (DEPTH) }\end{array}$ & $\begin{array}{l}\text { Credit depth of information index }(0=\text { low to } \\
6=\text { high })\end{array}$ & $\begin{array}{l}\text { World Bank World } \\
\text { Development Indicators }\end{array}$ & + \\
\hline $\begin{array}{l}\text { Strength of Legal Rights } \\
\text { (STRENGTH) }\end{array}$ & $\begin{array}{l}\text { Strength of legal rights index }(0=\text { weak to } \\
10=\text { strong })\end{array}$ & $\begin{array}{l}\text { World Bank World } \\
\text { Development Indicators }\end{array}$ & - \\
\hline Institutional Quality (INS) & $\begin{array}{l}\text { The sum of Bureaucracy Quality (out of } 4 \text { ), } \\
\text { Corruption (out of } 6 \text { ) and Law \& Order (out of } \\
\text { 6), where a score of } 0 \text { points to high risk and } \\
\text { the maximum score equates to low risk }\end{array}$ & $\begin{array}{l}\text { International Country Risk } \\
\text { Guide }\end{array}$ & - \\
\hline
\end{tabular}

\section{CInternational Monetary Fund. Not for Redistribution}




\begin{tabular}{|c|c|c|c|c|c|c|c|}
\hline \multicolumn{8}{|c|}{ Table 3: Descriptive Statistics ${ }^{8}$} \\
\hline & Armenia & Azerbaijan & Georgia & Kazakhstan & Tajikistan & Uzbekistan & CCA \\
\hline \multirow{2}{*}{ Net Interest Margin } & 7.28 & 7.84 & 11.87 & 7.36 & 9.13 & 6.72 & 8.15 \\
\hline & (2.73) & (3.37) & $(5.29)$ & (6.37) & (6.73) & (3.43) & $(5.21)$ \\
\hline Operating Cost: & 4.77 & 5.13 & 7.45 & 5.24 & 7.7 & 6 & 5.63 \\
\hline Overheads to Total Assets & (2.55) & $(3.28)$ & (3.47) & $(5.63)$ & (3.85) & (2.67) & $(4.25)$ \\
\hline Risk Aversion: & 23.7 & 19.5 & 24.9 & 21.06 & 25.04 & 15 & 21.37 \\
\hline Equity to Total Assets & $(16.02)$ & $(14.77)$ & $(16.24)$ & $(24.10)$ & (19.03) & (10.44) & $(18.91)$ \\
\hline Credit Risk: & 1.91 & 8.65 & 7.29 & 9.4 & 7.6 & 4.63 & 7.26 \\
\hline Loan Loss Reserves to Gross Loans & (1.53) & $(9.78)$ & $(5.06)$ & $(12.40)$ & (5.37) & (2.50) & (9.25) \\
\hline Size of Operation: & 4.7 & 5.36 & 5.97 & 6.13 & 7.33 & 5.38 & 5.69 \\
\hline Log of Total Assets & (1.49) & $(2.39)$ & (2.47) & $(1.97)$ & (3.16) & $(1.70)$ & $(2.20)$ \\
\hline Non-interest Activity: & 39.12 & 37.53 & 31.97 & 37.28 & 51.2 & 60.63 & 39.43 \\
\hline Non-Interest Income to Gross Revenues & $(50.92)$ & $(18.42)$ & $(14.76)$ & $(25.90)$ & $(25.10)$ & $(15.22)$ & (29.39) \\
\hline Opportunity Cost of Reserves: & 16.89 & 14.68 & 16.11 & 14.01 & 18.68 & 28.95 & 16.47 \\
\hline Cash to Total Assets & $(11.22)$ & $(9.89)$ & (7.32) & $(15.25)$ & $(10.35)$ & $(17.47)$ & $(13.30)$ \\
\hline & 27.15 & 32.31 & 38.69 & 29.38 & $\ldots$ & 29.31 & 30.88 \\
\hline Lerner Index & (6.28) & $(4.50)$ & (9.92) & $(4.11)$ & $\ldots$ & (9.33) & (7.46) \\
\hline & 4.31 & 5.18 & 6.25 & 8.01 & 12.39 & 13.41 & 7.8 \\
\hline Inflation & (3.03) & $(6.67)$ & $(4.65)$ & (3.55) & $(8.81)$ & (9.71) & (6.93) \\
\hline & 10.97 & 7.78 & 14.51 & 9.91 & 19.26 & 20.11 & 9.88 \\
\hline Policy Rate & $(10.11)$ & (3.23) & $(10.60)$ & $(5.01)$ & (3.44) & (8.33) & (6.26) \\
\hline & & & & & & & 3.55 \\
\hline Credit Depth of Intormation & & & & & & & (2.13) \\
\hline Strength of Legal Rights & & & & & & & $\begin{array}{r}4.34 \\
\end{array}$ \\
\hline & & & & & & & $\begin{array}{r}1.03) \\
6.87\end{array}$ \\
\hline Institutional Quality & & & & & & & $(1.00)$ \\
\hline
\end{tabular}

\footnotetext{
${ }^{8}$ Standard deviation in parenthesis.
} 


\begin{tabular}{|c|c|c|c|c|c|c|c|}
\hline \multicolumn{8}{|c|}{ Table 4: Determinants of Bank Interest Margins in the CCA } \\
\hline & $(1)$ & $(2)$ & (3) & (4) & (5) & (6) & (7) \\
\hline Lagged Net Interest Margin & $\begin{array}{l}0.553^{* * *} \\
(0.077)\end{array}$ & $\begin{array}{l}0.460 * * * \\
(0.098)\end{array}$ & $\begin{array}{l}0.601^{\star * *} \\
(0.079)\end{array}$ & $\begin{array}{l}0.538^{* * *} \\
(0.125)\end{array}$ & $\begin{array}{l}0.553^{* * *} \\
(0.081)\end{array}$ & $\begin{array}{l}0.527^{\star \star *} \\
(0.085)\end{array}$ & $\begin{array}{l}0.635^{\star * *} \\
(0.080)\end{array}$ \\
\hline Operating Cost & $\begin{array}{l}0.372^{\star \star \star} \\
(0.131)\end{array}$ & $\begin{array}{c}0.240 * \\
(0.136)\end{array}$ & $\begin{array}{l}0.420^{\star * *} \\
(0.128)\end{array}$ & $\begin{array}{l}0.353^{* *} \\
(0.137)\end{array}$ & $\begin{array}{l}0.550 * * \star \\
(0.132)\end{array}$ & $\begin{array}{l}0.524^{* * *} \\
(0.119)\end{array}$ & $\begin{array}{c}0.226^{\star} \\
(0.118)\end{array}$ \\
\hline Risk Aversion & $\begin{array}{l}-0.233 \\
(0.421)\end{array}$ & $\begin{array}{c}-0.16 \\
(0.347)\end{array}$ & $\begin{array}{c}-0.06 \\
(0.305)\end{array}$ & $\begin{array}{l}-0.218 \\
(0.740)\end{array}$ & $\begin{array}{c}0.017 \\
(0.525)\end{array}$ & $\begin{array}{l}-0.279 \\
(0.487)\end{array}$ & $\begin{array}{l}-0.506 \\
(0.397)\end{array}$ \\
\hline Credit Risk & $\begin{array}{c}0.011 \\
(0.024)\end{array}$ & $\begin{array}{l}-0.031 \\
(0.026)\end{array}$ & $\begin{array}{l}-0.002 \\
(0.023)\end{array}$ & $\begin{array}{c}0.025 \\
(0.033)\end{array}$ & $\begin{array}{l}-0.009 \\
(0.023)\end{array}$ & $\begin{array}{l}-0.004 \\
(0.024)\end{array}$ & $\begin{array}{c}0.027 \\
(0.027)\end{array}$ \\
\hline Size of Operation & $\begin{array}{l}0.038^{*} \\
(0.022)\end{array}$ & $\begin{array}{c}0.024 \\
(0.020)\end{array}$ & $\begin{array}{l}0.042^{* *} \\
(0.019)\end{array}$ & $\begin{array}{l}0.042^{*} \\
(0.023)\end{array}$ & $\begin{array}{l}0.047^{* \star} \\
(0.021)\end{array}$ & $\begin{array}{l}0.038^{* *} \\
(0.019)\end{array}$ & $\begin{array}{l}0.040 * * \\
(0.018)\end{array}$ \\
\hline Non-interest Activity & $\begin{array}{c}-0.045^{* *} \\
(0.022)\end{array}$ & $\begin{array}{c}-0.036^{*} \\
(0.019)\end{array}$ & $\begin{array}{c}-0.047^{\star *} \\
(0.020)\end{array}$ & $\begin{array}{c}-0.054^{*} \\
(0.030)\end{array}$ & $\begin{array}{c}-0.024^{*} \\
(0.013)\end{array}$ & $\begin{array}{c}-0.026^{\star *} \\
(0.012)\end{array}$ & $\begin{array}{c}-0.027^{*} \\
(0.016)\end{array}$ \\
\hline Opportunity Cost of Reserves & $\begin{array}{l}0.041^{* *} \\
(0.017)\end{array}$ & & & & & & \\
\hline Lerner Index & & $\begin{array}{c}0.11 \\
(0.074)\end{array}$ & & & & & \\
\hline Inflation & & & $\begin{array}{c}0.05 \\
(0.046)\end{array}$ & & & & \\
\hline Policy rate & & & & $\begin{array}{c}0.207 \\
(0.167)\end{array}$ & & & \\
\hline Credit Depth of Information & & & & & $\begin{array}{c}0.189 \\
(0.165)\end{array}$ & & \\
\hline Strength of Legal Rights & & & & & & $\begin{array}{l}-0.003 \\
(0.160)\end{array}$ & \\
\hline Institutional Quality & & & & & & & $\begin{array}{l}-0.126 \\
(1.110)\end{array}$ \\
\hline Time dummy & Yes & Yes & Yes & Yes & Yes & Yes & Yes \\
\hline Observations & 690 & 506 & 690 & 524 & 570 & 570 & 500 \\
\hline Number of clusters & 100 & 84 & 100 & 87 & 98 & 98 & 66 \\
\hline Number of instruments & 79 & 79 & 79 & 79 & 77 & 78 & 65 \\
\hline Hansen test $p$-value & 0.467 & 0.236 & 0.364 & 0.271 & 0.416 & 0.241 & 0.334 \\
\hline$A-B A R(1)$ test $p$-value & 0.002 & 0.014 & 0.001 & 0.029 & 0.006 & 0.007 & 0.001 \\
\hline$A-B A R(2)$ test $p$-value & 0.207 & 0.093 & 0.226 & 0.47 & 0.238 & 0.151 & 0.232 \\
\hline No. of banks & 110 & 110 & 110 & 110 & 110 & 110 & 110 \\
\hline
\end{tabular}




\begin{tabular}{|c|c|c|c|c|c|c|c|c|c|c|c|c|}
\hline \multicolumn{13}{|c|}{ Table 5: Determinants of Bank Interest Margins in Armenia } \\
\hline & (1) & (3) & (4) & (5) & (7) & (8) & (9) & (11) & (12) & (13) & (15) & (16) \\
\hline Operating Cost & $\begin{array}{l}0.520^{\star \star \star} \\
(0.081)\end{array}$ & $\begin{array}{l}0.520^{\star \star \star} \\
(0.070)\end{array}$ & $\begin{array}{l}0.510^{\star \star *} \\
(0.062)\end{array}$ & $\begin{array}{l}0.486^{\star \star \star} \\
(0.087)\end{array}$ & $\begin{array}{l}0.477^{\star \star *} \\
(0.091)\end{array}$ & $\begin{array}{l}0.433^{\star \star \star} \\
(0.077)\end{array}$ & $\begin{array}{l}0.493^{\star \star \star} \\
(0.078)\end{array}$ & $\begin{array}{l}0.493^{\star \star *} \\
(0.076)\end{array}$ & $\begin{array}{l}0.466^{\star \star \star} \\
(0.069)\end{array}$ & $\begin{array}{l}0.468^{\star \star \star} \\
(0.077)\end{array}$ & $\begin{array}{l}0.468^{\star \star \star} \\
(0.069)\end{array}$ & $\begin{array}{l}0.469^{\star \star \star} \\
(0.070)\end{array}$ \\
\hline Risk Aversion & $\begin{array}{l}0.077^{\star \star \star} \\
(0.019)\end{array}$ & $\begin{array}{l}0.077^{\star \star \star} \\
(0.019)\end{array}$ & $\begin{array}{l}0.080^{\star \star *} \\
(0.017)\end{array}$ & $\begin{array}{l}0.076^{\star \star \star} \\
(0.023)\end{array}$ & $\begin{array}{l}0.059^{\star *} \\
(0.024)\end{array}$ & $\begin{array}{l}0.085^{\star \star \star} \\
(0.022)\end{array}$ & $\begin{array}{l}0.077^{\star \star \star *} \\
(0.020)\end{array}$ & $\begin{array}{l}0.077^{\star \star \star} \\
(0.020)\end{array}$ & $\begin{array}{l}0.088^{\star \star *} \\
(0.019)\end{array}$ & $\begin{array}{l}0.075^{\star \star *} \\
(0.020)\end{array}$ & $\begin{array}{l}0.075^{\star * *} \\
(0.019)\end{array}$ & $\begin{array}{l}0.088^{\star \star *} \\
(0.019)\end{array}$ \\
\hline Credit Risk & $\begin{array}{l}-0.053 \\
(0.078)\end{array}$ & $\begin{array}{l}-0.053 \\
(0.114)\end{array}$ & $\begin{array}{l}-0.005 \\
(0.100)\end{array}$ & $\begin{array}{l}-0.113 \\
(0.119)\end{array}$ & $\begin{array}{l}-0.094 \\
(0.175)\end{array}$ & $\begin{array}{l}-0.067 \\
(0.157)\end{array}$ & $\begin{array}{l}-0.047 \\
(0.081)\end{array}$ & $\begin{array}{l}-0.047 \\
(0.123)\end{array}$ & $\begin{array}{r}0.013 \\
(0.113)\end{array}$ & $\begin{array}{l}-0.051 \\
(0.076)\end{array}$ & $\begin{array}{l}-0.051 \\
(0.113)\end{array}$ & $\begin{array}{r}0.010 \\
(0.114)\end{array}$ \\
\hline Size of Operation & $\begin{array}{l}0.820^{\star \star} \\
(0.313)\end{array}$ & $\begin{array}{l}0.820^{\star \star \star} \\
(0.318)\end{array}$ & $\begin{array}{l}1.054^{\star \star \star} \\
(0.280)\end{array}$ & $\begin{array}{l}0.870^{\star *} \\
(0.406)\end{array}$ & $\begin{array}{r}0.445 \\
(0.452)\end{array}$ & $\begin{array}{l}1.058^{\star \star \star} \\
(0.372)\end{array}$ & $\begin{array}{l}0.851^{\star \star} \\
(0.334)\end{array}$ & $\begin{array}{l}0.851^{\star \star} \\
(0.344)\end{array}$ & $\begin{array}{l}1.038^{\star \star *} \\
(0.316)\end{array}$ & $\begin{array}{l}0.925^{\star * *} \\
(0.317)\end{array}$ & $\begin{array}{l}0.925^{\star \star *} \\
(0.319)\end{array}$ & $\begin{array}{l}1.058^{\star \star \star *} \\
(0.323)\end{array}$ \\
\hline Non-interest Activity & $\begin{array}{l}-0.057^{\star \star \star} \\
(0.018)\end{array}$ & $\begin{array}{l}-0.057^{\star \star \star} \\
(0.013)\end{array}$ & $\begin{array}{l}-0.076^{\star \star \star} \\
(0.012)\end{array}$ & $\begin{array}{l}-0.039^{\star \star} \\
(0.019)\end{array}$ & $\begin{array}{l}-0.045^{\star \star \star} \\
(0.016)\end{array}$ & $\begin{array}{l}-0.047^{\star \star \star} \\
(0.014)\end{array}$ & $\begin{array}{l}-0.042^{\star \star} \\
(0.017)\end{array}$ & $\begin{array}{l}-0.042^{\star \star \star} \\
(0.014)\end{array}$ & $\begin{array}{l}-0.055^{\star \star \star} \\
(0.013)\end{array}$ & $\begin{array}{l}-0.039^{\star \star} \\
(0.017)\end{array}$ & $\begin{array}{l}-0.039 \star \star \star \\
(0.013)\end{array}$ & $\begin{array}{l}-0.056^{\star \star \star} \\
(0.013)\end{array}$ \\
\hline Opportunity Cost of Reserves & $\begin{array}{l}0.066^{\star \star \star} \\
(0.012)\end{array}$ & $\begin{array}{l}0.066^{\star \star \star} \\
(0.015)\end{array}$ & $\begin{array}{l}0.059^{\star * *} \\
(0.014)\end{array}$ & & & & & & & & & \\
\hline Lerner Index & & & & $\begin{array}{r}0.076 \\
(0.058)\end{array}$ & $\begin{array}{r}0.050 \\
(0.162)\end{array}$ & $\begin{array}{l}0.117^{\star \star} \\
(0.054)\end{array}$ & & & & & & \\
\hline Inflation & & & & & & & $\begin{array}{r}0.362 \\
(0.311)\end{array}$ & $\begin{array}{l}-0.149 \\
(0.585)\end{array}$ & $\begin{array}{l}0.657^{\star \star \star} \\
(0.189)\end{array}$ & & & \\
\hline Policy rate & & & & & & & & & & $\begin{array}{r}0.057 \\
(0.057)\end{array}$ & $\begin{array}{r}2.452 \\
(6.885)\end{array}$ & $\begin{array}{r}0.047 \\
(0.039)\end{array}$ \\
\hline Time dummy & Yes & Yes & Yes & Yes & Yes & Yes & Yes & Yes & Yes & Yes & Yes & Yes \\
\hline Observations & 125 & 125 & 125 & 98 & 98 & 97 & 125 & 125 & 124 & 122 & 122 & 122 \\
\hline No. of banks & 16 & 16 & 16 & 16 & 16 & 16 & 16 & 16 & 16 & 16 & 16 & 16 \\
\hline R-squared & 0.564 & & 0.680 & 0.497 & & 0.606 & 0.486 & & 0.605 & 0.469 & & 0.497 \\
\hline Hausman Test ( $p$-value) & & 1.000 & & & 0.770 & & & 0.363 & & & 0.945 & \\
\hline Type & Pooled & GLS & RREG & Pooled & GLS & RREG & Pooled & GLS & RREG & Pooled & GLS & RREG \\
\hline
\end{tabular}




\begin{tabular}{|c|c|c|c|c|c|c|c|c|c|c|c|c|}
\hline \multicolumn{13}{|c|}{ Table 6: Determinants of Bank Interest Margins in Azerbaijan } \\
\hline & (1) & (2) & (4) & (5) & (6) & (8) & (9) & (10) & (12) & (13) & (14) & (16) \\
\hline Operating Cost & $\begin{array}{l}0.390^{\star \star} \\
(0.158)\end{array}$ & $\begin{array}{l}0.195^{\star \star \star} \\
(0.062)\end{array}$ & $\begin{array}{l}0.635^{\star \star \star} \\
(0.084)\end{array}$ & $\begin{array}{r}0.292 \\
(0.177)\end{array}$ & $\begin{array}{l}0.139^{\star *} \\
(0.069)\end{array}$ & $\begin{array}{l}0.621^{\star \star \star} \\
(0.092)\end{array}$ & $\begin{array}{l}0.338^{\star \star} \\
(0.168)\end{array}$ & $\begin{array}{l}0.177^{\star \star \star} \\
(0.062)\end{array}$ & $\begin{array}{l}0.656^{\star \star \star} \\
(0.087)\end{array}$ & $\begin{array}{l}0.334^{\star \star} \\
(0.164)\end{array}$ & $\begin{array}{l}0.180^{\star \star \star} \\
(0.063)\end{array}$ & $\begin{array}{l}0.642^{\star \star \star} \\
(0.086)\end{array}$ \\
\hline Risk Aversion & $\begin{array}{r}0.032 \\
(0.034)\end{array}$ & $\begin{array}{r}-0.003 \\
(0.023)\end{array}$ & $\begin{array}{l}0.046^{\star \star \star} \\
(0.016)\end{array}$ & $\begin{array}{r}0.032 \\
(0.039)\end{array}$ & $\begin{array}{r}-0.011 \\
(0.026)\end{array}$ & $\begin{array}{l}0.038^{\star *} \\
(0.017)\end{array}$ & $\begin{array}{r}0.053 \\
(0.036)\end{array}$ & $\begin{array}{l}-0.014 \\
(0.023)\end{array}$ & $\begin{array}{l}0.052^{\star \star \star} \\
(0.016)\end{array}$ & $\begin{array}{r}0.049 \\
(0.035)\end{array}$ & $\begin{array}{r}-0.008 \\
(0.023)\end{array}$ & $\begin{array}{l}0.049^{\star \star \star} \\
(0.016)\end{array}$ \\
\hline Credit Risk & $\begin{array}{l}-0.049^{* \star} \\
(0.024)\end{array}$ & $\begin{array}{l}-0.049^{\star \star \star} \\
(0.018)\end{array}$ & $\begin{array}{l}-0.061^{\star \star \star} \\
(0.020)\end{array}$ & $\begin{array}{l}-0.056 \\
(0.036)\end{array}$ & $\begin{array}{l}-0.051^{\star *} \\
(0.020)\end{array}$ & $\begin{array}{l}-0.152^{\star \star \star} \\
(0.030)\end{array}$ & $\begin{array}{l}-0.054 \\
(0.035)\end{array}$ & $\begin{array}{l}-0.045^{\star \star} \\
(0.019)\end{array}$ & $\begin{array}{l}-0.105^{\star \star \star} \\
(0.030)\end{array}$ & $\begin{array}{l}-0.056 \\
(0.035)\end{array}$ & $\begin{array}{l}-0.048^{\star \star} \\
(0.019)\end{array}$ & $\begin{array}{l}-0.113^{\star \star \star} \\
(0.029)\end{array}$ \\
\hline Size of Operation & $\begin{array}{l}-0.384^{\star \star *} \\
(0.119)\end{array}$ & $\begin{array}{l}-0.614^{\star \star \star} \\
(0.178)\end{array}$ & $\begin{array}{l}-0.259^{\star \star \star *} \\
(0.084)\end{array}$ & $\begin{array}{l}-0.204 \\
(0.186)\end{array}$ & $\begin{array}{r}-0.073 \\
(0.254)\end{array}$ & $\begin{array}{r}0.082 \\
(0.111)\end{array}$ & $\begin{array}{l}-0.254^{\star \star} \\
(0.112)\end{array}$ & $\begin{array}{l}-0.727^{\star \star \star} \\
(0.182)\end{array}$ & $\begin{array}{l}-0.150^{\star} \\
(0.083)\end{array}$ & $\begin{array}{l}-0.223^{*} \\
(0.130)\end{array}$ & $\begin{array}{l}-0.526^{\star \star \star} \\
(0.195)\end{array}$ & $\begin{array}{l}-0.079 \\
(0.087)\end{array}$ \\
\hline Non-interest Activity & $\begin{array}{l}-0.099^{\star * \star} \\
(0.015)\end{array}$ & $\begin{array}{l}-0.106^{\star \star \star} \\
(0.017)\end{array}$ & $\begin{array}{l}-0.092^{\star \star \star *} \\
(0.012)\end{array}$ & $\begin{array}{l}-0.072^{\star \star \star} \\
(0.018)\end{array}$ & $\begin{array}{l}-0.082^{\star \star \star} \\
(0.019)\end{array}$ & $\begin{array}{l}-0.065^{\star \star \star} \\
(0.013)\end{array}$ & $\begin{array}{l}-0.069^{\star \star \star} \\
(0.014)\end{array}$ & $\begin{array}{l}-0.098^{\star \star \star} \\
(0.017)\end{array}$ & $\begin{array}{l}-0.055^{\star \star \star} \\
(0.012)\end{array}$ & $\begin{array}{l}-0.074^{\star \star \star} \\
(0.016)\end{array}$ & $\begin{array}{l}-0.102^{\star \star \star} \\
(0.017)\end{array}$ & $\begin{array}{l}-0.066^{\star \star \star} \\
(0.012)\end{array}$ \\
\hline Opportunity Cost of Reserves & $\begin{array}{l}0.113^{\star \star \star} \\
(0.023)\end{array}$ & $\begin{array}{l}0.078^{\star \star \star} \\
(0.022)\end{array}$ & $\begin{array}{l}0.114^{\star \star \star} \\
(0.020)\end{array}$ & & & & & & & & & \\
\hline Lerner Index & & & & $\begin{array}{r}0.096 \\
(0.081)\end{array}$ & $\begin{array}{l}0.168^{\star \star \star} \\
(0.061)\end{array}$ & $\begin{array}{l}0.212^{\star \star \star} \\
(0.059)\end{array}$ & & & & & & \\
\hline Inflation & & & & & & & $\begin{array}{r}0.041 \\
(0.032)\end{array}$ & $\begin{array}{l}0.078^{\star \star \star} \\
(0.026)\end{array}$ & $\begin{array}{l}0.075^{\star \star} \\
(0.029)\end{array}$ & & & \\
\hline Policy rate & & & & & & & & & & $\begin{array}{r}0.071 \\
(0.081)\end{array}$ & $\begin{array}{c}0.105^{*} \\
(0.058)\end{array}$ & $\begin{array}{l}0.171^{\star \star \star} \\
(0.061)\end{array}$ \\
\hline Time dummy & No & No & No & No & No & No & No & No & No & No & No & No \\
\hline Observations & 181 & 181 & 180 & 138 & 138 & 136 & 181 & 181 & 179 & 181 & 181 & 179 \\
\hline No. of banks & 24 & 24 & 24 & 24 & 24 & 24 & 24 & 24 & 24 & 24 & 24 & 24 \\
\hline $\begin{array}{l}\text { R-squared } \\
\text { Hausman Test (p-value) }\end{array}$ & 0.439 & $\begin{array}{l}0.287 \\
0.000\end{array}$ & 0.539 & 0.327 & $\begin{array}{l}0.244 \\
0.000\end{array}$ & 0.521 & 0.358 & $\begin{array}{l}0.273 \\
0.000\end{array}$ & 0.498 & 0.356 & $\begin{array}{l}0.246 \\
0.001\end{array}$ & 0.511 \\
\hline Type & Pooled & Fixed Effect & RREG & Pooled & Fixed Effect & RREG & Pooled & Fixed Effect & RREG & Pooled & Fixed Effect & RREG \\
\hline
\end{tabular}




\begin{tabular}{|c|c|c|c|c|c|c|c|c|c|c|c|c|}
\hline \multicolumn{13}{|c|}{ Table 7: Determinants of Bank Interest Margins in Georgia } \\
\hline & (1) & (3) & (4) & (5) & (6) & (8) & (9) & (11) & (12) & (13) & (15) & (16) \\
\hline Operating Cost & $\begin{array}{l}0.452^{* * *} \\
(0.126)\end{array}$ & $\begin{array}{l}0.452^{\star * *} \\
(0.115)\end{array}$ & $\begin{array}{l}0.293^{\star * *} \\
(0.086)\end{array}$ & $\begin{array}{l}0.650^{* * *} \\
(0.169)\end{array}$ & $\begin{array}{l}0.478^{* * *} \\
(0.158)\end{array}$ & $\begin{array}{l}0.535^{\star * *} \\
(0.106)\end{array}$ & $\begin{array}{l}0.648^{* * *} \\
(0.158)\end{array}$ & $\begin{array}{l}0.648^{* * *} \\
(0.120)\end{array}$ & $\begin{array}{l}0.424^{* * *} \\
(0.096)\end{array}$ & $\begin{array}{l}0.648^{* * *} \\
(0.158)\end{array}$ & $\begin{array}{l}0.648^{\star * *} \\
(0.120)\end{array}$ & $\begin{array}{l}0.424^{* * \star} \\
(0.096)\end{array}$ \\
\hline Risk Aversion & $\begin{array}{l}-0.030 \\
(0.021)\end{array}$ & $\begin{array}{l}-0.030 \\
(0.024)\end{array}$ & $\begin{array}{l}-0.011 \\
(0.018)\end{array}$ & $\begin{array}{l}-0.061^{* *} \\
(0.027)\end{array}$ & $\begin{array}{l}-0.175^{\star \star *} \\
(0.042)\end{array}$ & $\begin{array}{l}-0.020 \\
(0.024)\end{array}$ & $\begin{array}{l}-0.073^{* * *} \\
(0.025)\end{array}$ & $\begin{array}{l}-0.073^{* * *} \\
(0.025)\end{array}$ & $\begin{array}{l}-0.037^{\star} \\
(0.020)\end{array}$ & $\begin{array}{l}-0.073^{\star \star *} \\
(0.025)\end{array}$ & $\begin{array}{l}-0.073^{* \star *} \\
(0.025)\end{array}$ & $\begin{array}{l}-0.037^{*} \\
(0.020)\end{array}$ \\
\hline Credit Risk & $\begin{array}{l}-0.021 \\
(0.079)\end{array}$ & $\begin{array}{l}-0.021 \\
(0.074)\end{array}$ & $\begin{array}{l}-0.015 \\
(0.055)\end{array}$ & $\begin{array}{l}-0.013 \\
(0.176)\end{array}$ & $\begin{array}{r}0.161 \\
(0.131)\end{array}$ & $\begin{array}{l}-0.078 \\
(0.102)\end{array}$ & $\begin{array}{r}0.002 \\
(0.087)\end{array}$ & $\begin{array}{r}0.002 \\
(0.082)\end{array}$ & $\begin{array}{l}-0.009 \\
(0.066)\end{array}$ & $\begin{array}{r}0.002 \\
(0.087)\end{array}$ & $\begin{array}{r}0.002 \\
(0.082)\end{array}$ & $\begin{array}{l}-0.009 \\
(0.066)\end{array}$ \\
\hline Size of Operation & $\begin{array}{l}-0.021 \\
(0.126)\end{array}$ & $\begin{array}{l}-0.021 \\
(0.156)\end{array}$ & $\begin{array}{l}-0.001 \\
(0.116)\end{array}$ & $\begin{array}{r}0.108 \\
(0.180)\end{array}$ & $\begin{array}{r}0.723 \\
(0.958)\end{array}$ & $\begin{array}{r}0.181 \\
(0.156)\end{array}$ & $\begin{array}{r}0.044 \\
(0.158)\end{array}$ & $\begin{array}{r}0.044 \\
(0.171)\end{array}$ & $\begin{array}{r}0.064 \\
(0.138)\end{array}$ & $\begin{array}{r}0.044 \\
(0.158)\end{array}$ & $\begin{array}{r}0.044 \\
(0.171)\end{array}$ & $\begin{array}{r}0.064 \\
(0.138)\end{array}$ \\
\hline Non-interest Activity & $\begin{array}{l}-0.156^{* * *} \\
(0.027)\end{array}$ & $\begin{array}{l}-0.156^{* \star *} \\
(0.023)\end{array}$ & $\begin{array}{l}-0.133^{\star * *} \\
(0.018)\end{array}$ & $\begin{array}{l}-0.169^{* \star *} \\
(0.048)\end{array}$ & $\begin{array}{l}-0.280^{\star \star *} \\
(0.044)\end{array}$ & $\begin{array}{l}-0.137^{\star * *} \\
(0.026)\end{array}$ & $\begin{array}{l}-0.169^{\star \star *} \\
(0.032)\end{array}$ & $\begin{array}{l}-0.169^{* \star *} \\
(0.026)\end{array}$ & $\begin{array}{l}-0.132^{\star \star \star} \\
(0.021)\end{array}$ & $\begin{array}{l}-0.169^{\star \star \star} \\
(0.032)\end{array}$ & $\begin{array}{l}-0.169^{\star \star *} \\
(0.026)\end{array}$ & $\begin{array}{l}-0.132^{* * \star} \\
(0.021)\end{array}$ \\
\hline Opportunity Cost of Reserves & $\begin{array}{l}0.249^{* * *} \\
(0.045)\end{array}$ & $\begin{array}{l}0.249^{* * *} \\
(0.049)\end{array}$ & $\begin{array}{l}0.204^{\star * *} \\
(0.036)\end{array}$ & & & & & & & & & \\
\hline Lerner Index & & & & $\begin{array}{l}0.351^{* * *} \\
(0.115)\end{array}$ & $\begin{array}{l}0.541^{* * *} \\
(0.135)\end{array}$ & $\begin{array}{l}0.246^{* * *} \\
(0.068)\end{array}$ & & & & & & \\
\hline Inflation & & & & & & & $\begin{array}{l}0.460^{* * *} \\
(0.146)\end{array}$ & $\begin{array}{l}-1.557 \\
(6.816)\end{array}$ & $\begin{array}{l}0.331^{* *} \\
(0.130)\end{array}$ & & & \\
\hline Policy rate & & & & & & & & & & $\begin{array}{l}0.248^{\star * *} \\
(0.078)\end{array}$ & $\begin{array}{r}0.406 \\
(1.776)\end{array}$ & $\begin{array}{l}0.193^{\star * *} \\
(0.070)\end{array}$ \\
\hline Time dummy & Yes & Yes & Yes & Yes & Yes & Yes & Yes & Yes & Yes & Yes & Yes & Yes \\
\hline Observations & 133 & 133 & 133 & 106 & 106 & 106 & 133 & 133 & 133 & 133 & 133 & 133 \\
\hline No. of banks & 13 & 13 & 13 & 13 & 13 & 13 & 13 & 13 & 13 & 13 & 13 & 13 \\
\hline R-squared & 0.644 & & 0.680 & 0.532 & 0.652 & 0.561 & 0.561 & & 0.547 & 0.561 & & 0.547 \\
\hline Hausman Test ( $p$-value) & & 0.999 & & & 0.039 & & & 0.414 & & & 0.378 & \\
\hline Type & Pooled & GLS & RREG & Pooled & Fixed Effect & RREG & Pooled & GLS & RREG & Pooled & GLS & RREG \\
\hline
\end{tabular}




\begin{tabular}{|c|c|c|c|c|c|c|c|c|c|c|c|c|}
\hline \multicolumn{13}{|c|}{ Table 8: Determinants of Bank Interest Margins in Kazakhstan } \\
\hline & (1) & (2) & (4) & (5) & (6) & (8) & (9) & (10) & (12) & (13) & (14) & (16) \\
\hline Operating Cost & $\begin{array}{l}1.118^{* \star *} \\
(0.378)\end{array}$ & $\begin{array}{l}0.651^{* \star *} \\
(0.083)\end{array}$ & $\begin{array}{l}0.487^{\star \star \star} \\
(0.044)\end{array}$ & $\begin{array}{l}1.031^{\star \star *} \\
(0.392)\end{array}$ & $\begin{array}{l}0.303^{\star \star \star} \\
(0.082)\end{array}$ & $\begin{array}{l}0.486^{\star \star *} \\
(0.050)\end{array}$ & $\begin{array}{l}1.116^{\star \star *} \\
(0.379)\end{array}$ & $\begin{array}{l}0.574^{\star \star \star} \\
(0.088)\end{array}$ & $\begin{array}{l}0.501^{\star \star \star} \\
(0.048)\end{array}$ & $\begin{array}{l}1.116^{\star \star \star} \\
(0.379)\end{array}$ & $\begin{array}{l}0.574^{\star \star \star} \\
(0.088)\end{array}$ & $\begin{array}{l}0.501^{\star \star \star} \\
(0.048)\end{array}$ \\
\hline Risk Aversion & $\begin{array}{r}0.018 \\
(0.017)\end{array}$ & $\begin{array}{r}0.013 \\
(0.016)\end{array}$ & $\begin{array}{c}0.017^{*} \\
(0.009)\end{array}$ & $\begin{array}{r}0.021 \\
(0.020)\end{array}$ & $\begin{array}{c}0.028^{*} \\
(0.016)\end{array}$ & $\begin{array}{l}0.035^{\star \star *} \\
(0.012)\end{array}$ & $\begin{array}{r}0.019 \\
(0.017)\end{array}$ & $\begin{array}{r}0.023 \\
(0.017)\end{array}$ & $\begin{array}{l}0.021^{\star \star} \\
(0.010)\end{array}$ & $\begin{array}{r}0.019 \\
(0.017)\end{array}$ & $\begin{array}{r}0.023 \\
(0.017)\end{array}$ & $\begin{array}{l}0.021^{\star *} \\
(0.010)\end{array}$ \\
\hline Credit Risk & $\begin{array}{l}-0.124^{\star \star} \\
(0.049)\end{array}$ & $\begin{array}{l}-0.061^{* *} \\
(0.028)\end{array}$ & $\begin{array}{l}-0.012 \\
(0.015)\end{array}$ & $\begin{array}{l}-0.123^{*} \\
(0.073)\end{array}$ & $\begin{array}{l}-0.033 \\
(0.029)\end{array}$ & $\begin{array}{r}0.020 \\
(0.023)\end{array}$ & $\begin{array}{l}-0.133^{* * *} \\
(0.048)\end{array}$ & $\begin{array}{l}-0.070^{\star *} \\
(0.030)\end{array}$ & $\begin{array}{l}-0.028^{*} \\
(0.016)\end{array}$ & $\begin{array}{l}-0.133^{* * *} \\
(0.048)\end{array}$ & $\begin{array}{l}-0.070^{* *} \\
(0.030)\end{array}$ & $\begin{array}{l}-0.028^{*} \\
(0.016)\end{array}$ \\
\hline Size of Operation & $\begin{array}{r}0.386 \\
(0.285)\end{array}$ & $\begin{array}{r}0.175 \\
(0.427)\end{array}$ & $\begin{array}{l}-0.046 \\
(0.122)\end{array}$ & $\begin{array}{r}0.263 \\
(0.283)\end{array}$ & $\begin{array}{r}0.208 \\
(0.411)\end{array}$ & $\begin{array}{l}-0.040 \\
(0.143)\end{array}$ & $\begin{array}{r}0.317 \\
(0.285)\end{array}$ & $\begin{array}{l}-0.005 \\
(0.456)\end{array}$ & $\begin{array}{l}-0.095 \\
(0.131)\end{array}$ & $\begin{array}{r}0.317 \\
(0.285)\end{array}$ & $\begin{array}{l}-0.005 \\
(0.456)\end{array}$ & $\begin{array}{l}-0.095 \\
(0.131)\end{array}$ \\
\hline Non-interest Activity & $\begin{array}{l}-0.062^{*} \\
(0.032)\end{array}$ & $\begin{array}{l}-0.035^{\star \star *} \\
(0.008)\end{array}$ & $\begin{array}{l}-0.078^{* * *} \\
(0.006)\end{array}$ & $\begin{array}{l}-0.057^{\star} \\
(0.034)\end{array}$ & $\begin{array}{l}-0.022^{* * *} \\
(0.008)\end{array}$ & $\begin{array}{l}-0.065^{* * *} \\
(0.009)\end{array}$ & $\begin{array}{l}-0.060^{\star} \\
(0.031)\end{array}$ & $\begin{array}{l}-0.033^{* \star *} \\
(0.009)\end{array}$ & $\begin{array}{l}-0.068^{* * *} \\
(0.006)\end{array}$ & $\begin{array}{l}-0.060^{*} \\
(0.031)\end{array}$ & $\begin{array}{l}-0.033^{* * *} \\
(0.009)\end{array}$ & $\begin{array}{l}-0.068^{\star \star \star *} \\
(0.006)\end{array}$ \\
\hline Opportunity Cost of Reserves & $\begin{array}{l}0.055^{* *} \\
(0.027)\end{array}$ & $\begin{array}{l}0.119^{* * \star} \\
(0.021)\end{array}$ & $\begin{array}{l}0.071^{* * *} \\
(0.013)\end{array}$ & & & & & & & & & \\
\hline Lerner Index & & & & $\begin{array}{c}-0.067 \\
(0.274)\end{array}$ & $\begin{array}{l}0.502^{* * *} \\
(0.145)\end{array}$ & $\begin{array}{l}0.264^{* * *} \\
(0.076)\end{array}$ & & & & & & \\
\hline Inflation & & & & & & & $\begin{array}{r}0.165 \\
(0.214)\end{array}$ & $\begin{array}{l}-0.045 \\
(0.115)\end{array}$ & $\begin{array}{l}-0.090^{*} \\
(0.053)\end{array}$ & & & \\
\hline Policy rate & & & & & & & & & & $\begin{array}{l}-0.670^{\star \star \star \star} \\
(0.078)\end{array}$ & $\begin{array}{l}1.112^{\star \star \star} \\
(0.216)\end{array}$ & $\begin{array}{l}-0.712^{\star \star \star \star} \\
(0.126)\end{array}$ \\
\hline Time dummy & Yes & Yes & Yes & Yes & Yes & Yes & Yes & Yes & Yes & Yes & Yes & Yes \\
\hline Observations & 263 & 263 & 263 & 215 & 215 & 214 & 263 & 263 & 263 & 263 & 263 & 263 \\
\hline No. of banks & 31 & 31 & 31 & 31 & 31 & 31 & 31 & 31 & 31 & 31 & 31 & 31 \\
\hline R-squared & 0.481 & 0.555 & 0.712 & 0.451 & 0.433 & 0.629 & 0.475 & 0.489 & 0.657 & 0.475 & 0.489 & 0.657 \\
\hline Hausman Test (p-value) & & 0.000 & & & 0.000 & & & 0.000 & & & 0.000 & \\
\hline Type & Pooled & Fixed Effect & RREG & Pooled & Fixed Effect & RREG & Pooled & Fixed Effect & RREG & Pooled & Fixed Effect & RREG \\
\hline
\end{tabular}




\begin{tabular}{|c|c|c|c|c|c|c|c|c|c|}
\hline \multicolumn{10}{|c|}{ Table 9: Determinants of Bank Interest Margins in Tajikistan } \\
\hline & (1) & (2) & (4) & (5) & (7) & (8) & (9) & (10) & (12) \\
\hline Operating Cost & $\begin{array}{l}0.708^{* * *} \\
(0.209)\end{array}$ & $\begin{array}{r}0.873 \\
(0.651)\end{array}$ & $\begin{array}{l}0.849^{\star * *} \\
(0.180)\end{array}$ & $\begin{array}{c}0.642^{\star *} \\
(0.251)\end{array}$ & $\begin{array}{c}0.642^{* *} \\
(0.278)\end{array}$ & $\begin{array}{l}0.837^{* * *} \\
(0.160)\end{array}$ & $\begin{array}{c}0.642^{* *} \\
(0.251)\end{array}$ & $\begin{array}{r}0.716 \\
(0.703)\end{array}$ & $\begin{array}{l}0.837^{\star * *} \\
(0.160)\end{array}$ \\
\hline Risk Aversion & $\begin{array}{l}-0.001 \\
(0.054)\end{array}$ & $\begin{array}{l}-0.115 \\
(0.070)\end{array}$ & $\begin{array}{l}0.089^{\star *} \\
(0.032)\end{array}$ & $\begin{array}{r}0.026 \\
(0.055)\end{array}$ & $\begin{array}{r}0.026 \\
(0.048)\end{array}$ & $\begin{array}{l}0.143^{* * *} \\
(0.028)\end{array}$ & $\begin{array}{r}0.026 \\
(0.055)\end{array}$ & $\begin{array}{l}-0.109 \\
(0.077)\end{array}$ & $\begin{array}{l}0.143^{\star * *} \\
(0.028)\end{array}$ \\
\hline Credit Risk & $\begin{array}{l}-0.334 \\
(0.216)\end{array}$ & $\begin{array}{l}-0.375 \\
(0.297)\end{array}$ & $\begin{array}{l}-0.278 \\
(0.217)\end{array}$ & $\begin{array}{r}0.017 \\
(0.202)\end{array}$ & $\begin{array}{r}0.017 \\
(0.271)\end{array}$ & $\begin{array}{r}0.015 \\
(0.156)\end{array}$ & $\begin{array}{r}0.017 \\
(0.202)\end{array}$ & $\begin{array}{l}-0.096 \\
(0.273)\end{array}$ & $\begin{array}{r}0.015 \\
(0.156)\end{array}$ \\
\hline Size of Operation & $\begin{array}{l}-0.315 \\
(0.340)\end{array}$ & $\begin{array}{r}-3.800 \\
(3.150)\end{array}$ & $\begin{array}{l}-0.402 \\
(0.243)\end{array}$ & $\begin{array}{l}-0.241 \\
(0.381)\end{array}$ & $\begin{array}{r}-0.241 \\
(0.377)\end{array}$ & $\begin{array}{l}-0.293 \\
(0.217)\end{array}$ & $\begin{array}{l}-0.241 \\
(0.381)\end{array}$ & $\begin{array}{l}-4.821 \\
(3.374)\end{array}$ & $\begin{array}{l}-0.293 \\
(0.217)\end{array}$ \\
\hline Non-interest Activity & $\begin{array}{l}-0.184^{* * *} \\
(0.058)\end{array}$ & $\begin{array}{l}-0.214^{\star \star} \\
(0.073)\end{array}$ & $\begin{array}{l}-0.164^{* * *} \\
(0.034)\end{array}$ & $\begin{array}{l}-0.166^{\star \star} \\
(0.057)\end{array}$ & $\begin{array}{l}-0.166^{\star \star \star} \\
(0.052)\end{array}$ & $\begin{array}{l}-0.141^{* * *} \\
(0.030)\end{array}$ & $\begin{array}{l}-0.166^{\star \star} \\
(0.057)\end{array}$ & $\begin{array}{l}-0.214^{\star \star} \\
(0.080)\end{array}$ & $\begin{array}{l}-0.141^{\star \star \star} \\
(0.030)\end{array}$ \\
\hline Opportunity Cost of Reserves & $\begin{array}{c}0.213^{*} \\
(0.101)\end{array}$ & $\begin{array}{r}0.242 \\
(0.138)\end{array}$ & $\begin{array}{c}0.153^{*} \\
(0.079)\end{array}$ & & & & & & \\
\hline Inflation & & & & $\begin{array}{l}-0.633^{*} \\
(0.305)\end{array}$ & $\begin{array}{l}-0.085 \\
(0.280)\end{array}$ & $\begin{array}{l}-0.323^{*} \\
(0.181)\end{array}$ & & & \\
\hline Policy rate & & & & & & & $\begin{array}{r}0.580 \\
(0.477)\end{array}$ & $\begin{array}{r}0.993 \\
(0.611)\end{array}$ & $\begin{array}{l}-0.148 \\
(0.272)\end{array}$ \\
\hline Time dummy & Yes & Yes & Yes & Yes & Yes & Yes & Yes & Yes & Yes \\
\hline Observations & 31 & 31 & 31 & 31 & 31 & 30 & 31 & 31 & 30 \\
\hline No. of banks & 7 & 7 & 7 & 7 & 7 & 7 & 7 & 7 & 7 \\
\hline R-squared & 0.909 & 0.906 & 0.961 & 0.888 & & 0.968 & 0.888 & 0.878 & 0.968 \\
\hline Hausman Test ( $p$-value) & & 0.0655 & & & 0.5693 & & & 0.0001 & \\
\hline Type & Pooled & Fixed Effect & RREG & Pooled & GLS & RREG & Pooled & Fixed Effect & RREG \\
\hline
\end{tabular}




\begin{tabular}{|c|c|c|c|c|c|c|c|c|c|c|c|c|}
\hline \multicolumn{13}{|c|}{ Table 10: Determinants of Bank Interest Margins in Uzbekistan } \\
\hline & (1) & (2) & (4) & (5) & (6) & (8) & (9) & (10) & (12) & (13) & (14) & (16) \\
\hline Operating Cost & $\begin{array}{l}0.453^{\star \star \star} \\
(0.126)\end{array}$ & $\begin{array}{c}0.541^{\star *} \\
(0.265)\end{array}$ & $\begin{array}{l}0.560^{\star \star \star} \\
(0.066)\end{array}$ & $\begin{array}{c}0.561^{\star \star} \\
(0.216)\end{array}$ & $\begin{array}{c}1.240^{*} \\
(0.598)\end{array}$ & $\begin{array}{l}0.661^{* * *} \\
(0.152)\end{array}$ & $\begin{array}{c}0.412^{\star *} \\
(0.161)\end{array}$ & $\begin{array}{c}0.660^{*} \\
(0.349)\end{array}$ & $\begin{array}{l}0.537^{\star \star *} \\
(0.127)\end{array}$ & $\begin{array}{c}0.347^{\star \star} \\
(0.158)\end{array}$ & $\begin{array}{c}0.686^{*} \\
(0.358)\end{array}$ & $\begin{array}{l}0.362^{\star * *} \\
(0.132)\end{array}$ \\
\hline Risk Aversion & $\begin{array}{r}0.039 \\
(0.033)\end{array}$ & $\begin{array}{r}-0.119 \\
(0.073)\end{array}$ & $\begin{array}{r}0.020 \\
(0.023)\end{array}$ & $\begin{array}{c}-0.055 \\
(0.050)\end{array}$ & $\begin{array}{r}-0.075 \\
(0.120)\end{array}$ & $\begin{array}{r}-0.033 \\
(0.043)\end{array}$ & $\begin{array}{r}-0.009 \\
(0.043)\end{array}$ & $\begin{array}{r}-0.094 \\
(0.086)\end{array}$ & $\begin{array}{r}-0.019 \\
(0.042)\end{array}$ & $\begin{array}{r}-0.010 \\
(0.038)\end{array}$ & $\begin{array}{c}-0.092 \\
(0.085)\end{array}$ & $\begin{array}{c}-0.032 \\
(0.041)\end{array}$ \\
\hline Credit Risk & $\begin{array}{r}0.112 \\
(0.114)\end{array}$ & $\begin{array}{c}0.219^{*} \\
(0.113)\end{array}$ & $\begin{array}{r}0.051 \\
(0.058)\end{array}$ & $\begin{array}{r}0.223 \\
(0.157)\end{array}$ & $\begin{array}{r}0.224 \\
(0.173)\end{array}$ & $\begin{array}{r}0.122 \\
(0.104)\end{array}$ & $\begin{array}{r}0.078 \\
(0.146)\end{array}$ & $\begin{array}{c}0.261^{*} \\
(0.134)\end{array}$ & $\begin{array}{r}0.111 \\
(0.115)\end{array}$ & $\begin{array}{r}0.117 \\
(0.133)\end{array}$ & $\begin{array}{c}0.262^{*} \\
(0.134)\end{array}$ & $\begin{array}{l}0.254^{* *} \\
(0.120)\end{array}$ \\
\hline Size of Operation & $\begin{array}{l}-0.716^{\star *} \\
(0.271)\end{array}$ & $\begin{array}{l}-0.563 \\
(0.441)\end{array}$ & $\begin{array}{l}-0.454^{\star \star \star} \\
(0.114)\end{array}$ & $\begin{array}{l}-0.755^{\star} \\
(0.418)\end{array}$ & $\begin{array}{r}0.392 \\
(0.640)\end{array}$ & $\begin{array}{l}-0.726^{\star \star *} \\
(0.224)\end{array}$ & $\begin{array}{l}-0.906^{\star \star \star} \\
(0.275)\end{array}$ & $\begin{array}{r}0.228 \\
(0.452)\end{array}$ & $\begin{array}{l}-0.735^{\star * \star} \\
(0.214)\end{array}$ & $\begin{array}{l}-1.123^{\star \star \star} \\
(0.295)\end{array}$ & $\begin{array}{r}0.469 \\
(0.553)\end{array}$ & $\begin{array}{l}-1.342^{\star \star *} \\
(0.273)\end{array}$ \\
\hline Non-interest Activity & $\begin{array}{l}-0.095^{\star \star \star} \\
(0.020)\end{array}$ & $\begin{array}{l}-0.110^{\star \star \star} \\
(0.019)\end{array}$ & $\begin{array}{l}-0.107^{\star \star \star} \\
(0.011)\end{array}$ & $\begin{array}{l}-0.087^{* *} \\
(0.033)\end{array}$ & $\begin{array}{l}-0.106^{\star \star \star} \\
(0.035)\end{array}$ & $\begin{array}{l}-0.065^{\star \star *} \\
(0.023)\end{array}$ & $\begin{array}{l}-0.079^{\star \star \star} \\
(0.028)\end{array}$ & $\begin{array}{l}-0.104^{* \star \star} \\
(0.022)\end{array}$ & $\begin{array}{l}-0.096^{\star \star *} \\
(0.021)\end{array}$ & $\begin{array}{l}-0.085^{\star \star *} \\
(0.026)\end{array}$ & $\begin{array}{l}-0.103^{* * *} \\
(0.022)\end{array}$ & 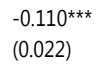 \\
\hline Opportunity Cost of Reserves & $\begin{array}{l}0.088^{* * *} \\
(0.014)\end{array}$ & $\begin{array}{l}0.110^{* \star \star} \\
(0.029)\end{array}$ & $\begin{array}{l}0.088^{* \star *} \\
(0.009)\end{array}$ & & & & & & & & & \\
\hline Lerner Index & & & & $\begin{array}{r}-0.020 \\
(0.096)\end{array}$ & $\begin{array}{l}-0.036 \\
(0.082)\end{array}$ & $\begin{array}{r}0.017 \\
(0.072)\end{array}$ & & & & & & \\
\hline Inflation & & & & & & & $\begin{array}{l}-0.099 * * \\
(0.046)\end{array}$ & $\begin{array}{r}0.065 \\
(0.090)\end{array}$ & $\begin{array}{l}-0.062 \\
(0.089)\end{array}$ & & & \\
\hline Policy rate & & & & & & & & & & $\begin{array}{l}-0.184^{*} \\
(0.092)\end{array}$ & $\begin{array}{r}0.079 \\
(0.100)\end{array}$ & $\begin{array}{l}-0.422^{\star \star \star} \\
(0.142)\end{array}$ \\
\hline \multicolumn{13}{|l|}{ Time dummy } \\
\hline Observations & 62 & 62 & 62 & 39 & 39 & 39 & 62 & 62 & 62 & 62 & 62 & 61 \\
\hline No. of banks & 19 & 19 & 19 & 19 & 19 & 19 & 19 & 19 & 19 & 19 & 19 & 19 \\
\hline R-squared & 0.748 & 0.587 & 0.861 & 0.633 & 0.580 & 0.704 & 0.561 & 0.447 & 0.587 & 0.596 & 0.448 & 0.612 \\
\hline Hausman Test (p-value) & & 0.015 & & & 0.000 & & & 0.022 & & & 0.010 & \\
\hline Type & Pooled & Fixed Effect & RREG & Pooled & Fixed Effect & RREG & Pooled & Fixed Effect & RREG & Pooled & Fixed Effect & RREG \\
\hline
\end{tabular}




\begin{tabular}{|c|c|c|c|c|c|c|c|c|c|c|c|c|c|}
\hline & ARM & & AZE & & GEO & & KAZ & & TJK & & UZB & & GMM \\
\hline Lagged Net Interest Margin & & & & & & & & & & & & & $0.558 * * *$ \\
\hline Operating Cost & 0.470 & $* * *$ & 0.639 & $* * *$ & 0.419 & $* * \star$ & 0.494 & $* * *$ & 0.841 & $* * *$ & 0.530 & $* * *$ & $0.342 * * *$ \\
\hline Risk Aversion & 0.085 & *** & 0.046 & $* * *$ & -0.026 & * & 0.024 & $* * *$ & 0.125 & $* * *$ & -0.016 & & 0.035 ** \\
\hline Credit Risk & -0.012 & & -0.108 & $* \star *$ & -0.028 & & -0.012 & * & -0.083 & & 0.135 & ** & 0.003 \\
\hline Size of Operation & 1.052 & *** & -0.102 & $* * *$ & 0.077 & & -0.069 & & -0.329 & & -0.814 & $* * *$ & -0.405 \\
\hline Non-interest Activity & -0.059 & *** & -0.070 & $* * *$ & -0.134 & $* * *$ & -0.070 & *** & -0.149 & $\star * *$ & -0.095 & *** & $-0.034^{* * *}$ \\
\hline Opportunity Cost of Reserves & 0.059 & *** & 0.114 & $* * *$ & 0.204 & $* * *$ & 0.071 & $* * *$ & 0.153 & * & 0.088 & $* * *$ & $0.039 * *$ \\
\hline Lerner Index & 0.117 & ** & 0.212 & $* * *$ & 0.246 & $* * *$ & 0.264 & $* * *$ & & & 0.017 & & 0.102 \\
\hline Inflation & 0.657 & $* * *$ & 0.075 & ** & 0.331 & ** & -0.090 & * & -0.323 & * & -0.062 & & 0.045 \\
\hline Policy rate & 0.047 & & 0.171 & $* * *$ & 0.193 & $* * *$ & -0.712 & $* * *$ & -0.148 & & -0.422 & *** & 0.045 \\
\hline Credit Depth of Information & & & & & & & & & & & & & 0.293 \\
\hline Strength of Legal Rights & & & & & & & & & & & & & 0.112 \\
\hline Institutional Quality & & & & & & & & & & & & & -0.126 \\
\hline Time dummy & Yes & & No & & Yes & & Yes & & Yes & & No & & Yes \\
\hline No. of banks & 16 & & 24 & & 13 & & 31 & & 7 & & 19 & & 110 \\
\hline R-squared & 0.597 & & 0.517 & & 0.584 & & 0.664 & & 0.966 & & 0.691 & & \\
\hline
\end{tabular}

